NBER WORKING PAPER SERIES

\title{
DIVERSITY AND CROWD-OUT: \\ A THEORY OF COLD-GLOW GIVING
}

\author{
Daniel M. Hungerman \\ Working Paper 13348 \\ http://www.nber.org/papers/w13348
NATIONAL BUREAU OF ECONOMIC RESEARCH
1050 Massachusetts Avenue
Cambridge, MA 02138
August 2007

Thanks to Kevin Baker, Kasey Buckles, Raj Chetty, Janet Currie, Tom Gresik, Bill Harbaugh, Louis Kaplow, Erzo F. P. Luttmer, Jim Stehle, John Straub, Jim Sullivan, Jake Vigdor, Abbie Wozniak, and seminar participants at the NBER Social Insurance Workshop, the Center for Operations Research and Econometrics (CORE), the University of Wisconsin-Milwaukee, Tufts University, Indiana University, the Law School at Notre Dame, and Columbia University. This work was supported by the Metanexus Institute. Email the author at dhungerm@nd.edu. The views expressed herein are those of the author(s) and do not necessarily reflect the views of the National Bureau of Economic Research.

(c) 2007 by Daniel M. Hungerman. All rights reserved. Short sections of text, not to exceed two paragraphs, may be quoted without explicit permission provided that full credit, including $\odot$ notice, is given to the source. 
Diversity and Crowd-out: A Theory of Cold-Glow Giving

Daniel M. Hungerman

NBER Working Paper No. 13348

August 2007

JEL No. H41,I38,J15,Z12

\begin{abstract}
Research has repeatedly shown that altruism is lower in diverse communities. Can this phenomenon be counteracted by government intervention? To answer this question, this paper introduces diversity to the canonical model of "warm glow" giving. Diversity may have two effects on incentives: it may attenuate individuals' altruistic preferences for public goods, and it may "cool off" the warm glow that individuals get from voluntarism. Either of these effects leads to diverse communities having lower levels of public goods, consistent with prior research. However, these effects have opposite implications for the efficacy of government intervention. I then empirically investigate whether government intervention is more effective in diverse communities. For identification, I exploit the Supreme Courtmandated 1991 expansion of the SSI program. Using a new dataset of United Methodist churches from 1984 to 2000, the results show that the expansion of SSI crowded-out charitable spending by churches. The crowd-out estimate for the average church is reasonably large, but this masks significant differences in crowd-out between communities. Crowd-out occurred almost entirely in relatively homogeneous communities; there is only modest evidence of crowd-out in racially diverse communities. Thus diverse communities, while having the lowest levels of altruism, are in this instance the most amenable to government intervention.
\end{abstract}

Daniel M. Hungerman

Department of Economics

University of Notre Dame

439 Flanner Hall

Notre Dame, IN 46556-5602

and NBER

dhungerm@nd.edu 


\section{Introduction}

Research has repeatedly shown that altruistic behavior is lower in diverse communities. Diversity has been associated with individuals contributing less to educational institutions (Miguel and Gugerty, 2005), becoming less charitably generous (Hungerman, 2007), favoring income redistribution less (Luttmer, 2001), supporting the government less (Vigdor, 2004; Macculloch, 2005), and volunteering and participating in community organizations less (Costa and Kahn, 2003a, 2003b; Alesina and La Ferrara, 2000, Okten and Osili, 2004). But while most studies agree that diversity lowers altruistic activities, these studies shed little light on positive questions of whether diversity might also impact the efficacy of government intervention. In this paper, I explore the relationship between diversity and public good provision. The focus is not on how diversity impacts the decisions made by the government, which has been amply studied. Instead, the focus is on how diversity impacts whether decisions made by the government are negated by crowd-out.

Such a focus may improve researchers' understanding of crowd-out itself. As discussed in the next section, the crowd-out literature has produced a wide array of empirical estimates. Yet excepting the well-known paper by Ribar and Wilhelm (2002), researchers have not attempted to address the lack of empirical consensus in this literature. This paper will explore whether community characteristics can help explain variation in crowd-out estimates. The characteristic emphasized here-diversity—makes a good starting point both because of its salient place in the literature and because it may explain divergent crowd-out estimates in situations where Ribar and Wilhelm's model cannot.

I begin by generalizing the canonical model of altruism, the warm glow model. The model considers the voluntary provision of a public good and posits that two forces may influence provision of the good. First, individuals may voluntarily contribute to a public good because they value the public good and want more of it—-that is, individuals are motivated by "pure altruism.” Second, individuals may contribute to a public good not because they care about the level of the public good but because they care about contributions per se; this is known as the "warm glow" incentive for contributions. 
I generalize the model by allowing diversity to influence preferences for voluntary behavior through either of these channels. First, diversity may attenuate purely altruistic motivations to contribute to the public good: as a community grows more diverse, individuals may care less about how much of the public good is provided for everyone. Second, diversity may “cool off” an individual's warm glow. For instance, if an individual's warm glow is driven by the desire for reputation or status, then as the community becomes more diverse the individual cares less about what others think of him, and the warm glow is consequently cooled off.

Either of these two effects leads to diverse communities having lower levels of public goods. However, the effects have opposite implications for the efficacy of government intervention. If the first effect dominates, so that diversity works by attenuating purely altruistic incentives, then in diverse communities people will only give because of a warm glow. In this case, diverse communities have the lowest levels of public goods but they nonetheless are the most amenable to government intervention; people in diverse communities will be unwilling to substitute government donations for their own and crowd-out will be small. If the second effect dominates, then in diverse communities the warm glow incentive has "turned cold" and individuals only give for altruistic reasons. In this case government intervention will be particularly ineffective in diverse communities.

I then empirically investigate the efficacy of government intervention in diverse communities relative to other communities. Of course, unobserved phenomena may impact both government intervention and voluntarism, complicating empirical studies of crowd-out. I overcome this issue by exploiting the U.S. Supreme Court's 1991 expansion of the Supplemental Security Income program for children, a large and plausibly exogenous instance of government intervention in a major means-tested program. Importantly, there is significant variation in the intensity of this intervention across both homogeneous and diverse communities. I know of no other research which has examined the crowd-out implications of this large program expansion. There are a number of caveats to consider when using this policy expansion; they are discussed more in section 4. 
To see how the court ruling impacts charitable contributions, I use a dataset of charitable activities undertaken by churches in the United Methodist denomination, one of the largest denominations in the country. The dataset contains church-level information on over 20,000 churches each year from 1984 to 2000. The data contain information on each church's county of residence, allowing each church's charitable activities to be compared with local government spending. This dataset has not been used in prior academic research.

The results show that the rise in SSI spending following the 1991 court ruling crowded-out charitable spending by churches. Similar to Hungerman (2005), the results are reasonably large in size; extrapolating the estimate to other denominations, the results suggest that a one-dollar rise in SSI spending in the early 1990s crowded-out about 15 cents of church spending. However, this crowd-out occurred almost entirely in communities that were relatively racially homogeneous. There is only modest evidence of crowd-out in racially diverse communities; in many specifications the results cannot reject the hypothesis that crowd-out in diverse communities is zero.

These findings provide strong evidence that crowd-out can vary across different communities. This fact may have implications for prior empirical estimates of crowd-out, but it also raises important welfare issues. Most empirical work in crowd-out has focused on questions of efficiency; these results indicate that the welfare consequences of crowd-out involve issues of equity as well. The results here might also have implications for research in areas related to crowd-out, particularly work on the flypaper effect. These implications are discussed more in the conclusions.

The next section discusses past work on crowd-out and on diversity. Section 3 lays out the model. Section 4 describes SSI’s expansion, and presents data and results. Section 5 concludes.

\section{Relation to Past Work}

2A. Crowd-out

Despite significant improvements in empirical methodology, in recent years the crowd-out literature has produced a variety of estimates of government crowd-out on various altruistic behaviors. 
Almost no work has tried to explain this empirical variation. One exception is the well-known paper by Ribar and Wilhelm (2002) which points out that differences in observable characteristics across communities may help explain differences in crowd-out estimates. The focus of their paper is community size. They show, under certain conditions, that as the population in a community grows the warm glow will come to dominate altruistic incentives to give. Crowd-out in small communities may consequently look different from crowd-out in large communities.

The paper's insight is certainly useful, but it fails to address the fact that divergent estimates of crowd-out persist even among studies where the relevant community sizes are comparably large (cf. Payne, 1998; Khanna and Sandler, 2000; Saunders, 2005; Straub and Manzoor, 2005; Hungerman, 2005; Gruber and Hungerman, 2007). To be sure, some of the discrepancy in the estimates of these studies is likely due to these papers considering crowd-out in different sectors. But even when looking at similar sectors, significantly different estimates can be found (e.g., Hungerman 2005; and Gruber and Hungerman, 2007; Kingma, 1989, Straub and Manzoor, 2005). This raises the question of whether environmental factors beyond community size may affect crowd-out.

\section{B. Diversity}

Perhaps the foremost environmental factor to consider is community diversity. A large literature has considered how diversity may affect the level of public goods in a community. Many of the papers in this literature follow the vanguard study by Alesina, Baqir, and Easterly (1999) which argues that polarized preferences for public goods can lead to lower support by the median voter for public good provision. Subsequent studies have explored how diversity may impact public good provision through a variety of public institutions (for example, Poterba, 1997, Alesina, Baqir, and Easterly, 1999; and Alesina, Baqir, and Hoxby, 2004). These studies essentially examine how diversity impacts government decisions, but have little to say about situations when goods are jointly provided.

The focus here will be on how diversity impacts whether decisions made by the government are negated by crowd-out. The focus is consequently on altruistic activities, or more specifically on activities that may be jointly provided by both individuals and the government. Such activities have received 
empirical attention in for example Fong (2006), Fong and Luttmer (2006), Hungerman (2007), Luttmer (2001), Okten and Osili (2004), Vigdor (2004) and Alesina and La Ferrara (2000). But this body of work has little to say on whether diversity may affect the efficacy of government intervention. This paper thus focuses on an important aspect of altruism and diversity-policy implications related to government intervention—overlooked by prior research.

\section{Model}

The model below explores diversity's impact on the level of jointly provided public goods and on the net efficacy of government provision of such goods. Before presenting the model, a few preliminary comments are in order.

First, the introduction of a warm glow is a somewhat "reduced form" specification of preferences and it invites multiple interpretations for how diversity may influence decisions. Here, the point of the model is not to isolate a specific mechanism by which diversity affects giving, but rather to highlight a broad ambiguity in how diversity affects government intervention. If diversity primarily attenuates altruistic tastes for a public good, then diverse communities may be relatively amenable to intervention. If diversity primarily attenuates the value of giving per se, which may occur for any number of reasons, then diverse communities will be the least amenable to intervention.

While the warm glow-based preference relation may be motivated by a number of different scenarios, some of these scenarios are certainly amenable to letting warm glow depend upon social context. For example, Hollander (1990) suggests people give in part to obtain "social approval," Harbaugh (1998a, 1998b) suggests that “prestige” may motivate giving, Glazer and Konrad (1996) refer to "status" as a motivator, and Bénabou and Tirole (2006) argue that reputational concerns may influence giving. The model follows Romano and Yildirim's (2001) observation that giving where a voluntary donation is itself valuable and depends upon social circumstances may be represented as warm glow.

Second, the model introduces diversity to the canonical warm-glow model by supposing that members of a community live on a unidimensional line, and that the distance between person i's location 
on the line and the average community member's location on the line affects $i$ 's preferences. The idea that individuals are sensitive to the average community member's characteristics seems reasonable in light of work showing that the average characteristics of community members play a salient role in determining altruistic behavior. Laboratory experiments (e.g., Hoffman, McCabe, and Smith, 1996; Eckel and Grossman, 1996; Fong and Lutmer, 2006) show that perceptions of public-good recipients affect altruism, and that an increase in the "social distance" between an individual and charitable recipients leads to lower levels of altruism. As discussed in Section 2, work in non-experimental settings suggests that individuals are sensitive to the characteristics of the local population when undertaking voluntarism. The model here captures this notion in a straightforward way by allowing individuals' decisions to donate to the public good to depend upon their perception of the typical community member. Furthermore, while the past research suggests that diversity is a community characteristic likely to affect giving, it should be clear that the model's implications could extend to essentially any characteristic that impacts incentives to give. This is discussed more in the conclusion.

Third, analyses of models of impure altruism often require strong assumptions on preferences. Results are oftentimes derived by appealing to quasi-linear preferences (Cornes and Sandler, 1994, 1999) or by imposing restrictions which ensure that the utility function's cross-partials with respect to the level of the public good are zero (Ribar and Wilhelm, 2002). ${ }^{1}$ Fortunately, such strong assumptions on the cross-partials of utility will not be necessary in what follows.

Finally, as with virtually all crowd-out theory, government intervention in the model is exogenous. Such a stylization is often reasonable in situations where goods are provided by the government and by individual altruism. For example, in the empirical section I focus on the response of churchgoers to an intervention mandated by the Supreme Court, an intervention which may be argued to be exogenous. Extending the model to strategic government intervention is left for future research.

\section{A. Basic Setup}

\footnotetext{
${ }^{1}$ The restriction in Ribar and Wilhelm's model can be seen from Lemma 3 in the appendix of their paper.
} 
Consider a model of impure altruism where there are $n$ individuals in a community. Individual $i$ 's utility is derived from consuming a purely private $\operatorname{good} c_{i}$, the level of a public good $Y$ provided in the community, and from i's own voluntary donation to the public good, $g_{i}$.

Following the canonical model of community diversity introduced by Alesina, Baqir, and Easterly (1999) suppose that individuals in this community are located along a unidimensional line. When individuals decide how much to contribute to the public good, they take the characteristics of the typical beneficiary (that is, the typical community member) into account. In particular, individuals are influenced by the distance between their location on the line and the average community member's location on the line. Let $\delta_{i} \geq 0$ represent the distance between individual $i$ and the average individual.

The utility of individual $i$ in the community is represented by

$$
U=U_{i}\left(c_{i}, Y, g_{i}, \delta_{i}\right)
$$

where the function $U_{i}$ is strictly quasi-concave and increasing in $c_{i}, Y$, and $g_{i}$ (we will not make any assumptions about the first-order impact of $\delta_{i}$ on utility).

Individual $i$ is endowed with income $\omega_{i}$ and pays lump sum taxes $\tau_{i}$, where $\tau_{i} \leq \omega_{i}$. A simple linear technology converts donations and tax payments into the public good so that $Y=G+T$, where $G=\sum_{i=1}^{N} g_{i}$ and $T=\sum_{i=1}^{N} \tau_{i}$. The individual's budget constraint is

$$
c_{i}+g_{i}=\omega_{i}-\tau_{i}
$$

Defining $Y_{-i}=\sum_{j \neq i} g_{j}+\tau_{j}$, we can add $Y_{-i}$ to both sides of (2) and rearrange terms to get:

$$
c_{i}=\omega_{i}+Y_{-i}-Y
$$

Similarly, $g_{i}=Y-Y_{-i}-\tau_{i}$. Using this and the expression in (3), under a Nash Equilibrium the individual's maximization problem becomes

$$
\max _{Y} U=U_{i}\left(\omega_{i}+Y_{-i}-Y, Y, Y-Y_{-i}-\tau_{i}, \delta_{i}\right)
$$


where $Y_{-i}, \omega_{i}, \tau_{i}$, and $\delta_{i}$ are all taken as given. The first-order condition for this problem is

$$
U_{i c}=U_{i Y}+U_{i g}
$$

where $U_{i c}$ is the derivative of $U_{i}$ with respect to $c$, and similarly for $U_{i Y}$ and $U_{i g}$. This implicitly defines an optimal level of the public good for person $i, Y^{*}=f_{i}\left(\omega_{i}+Y_{-i}, Y_{-i}+\tau_{i}, \delta_{i}\right){ }^{2}$ Person $i$ 's voluntary donation may be expressed as $g_{i}^{*}=f_{i}\left(\omega_{i}+Y_{-i}, Y_{-i}+\tau_{i}, \delta_{i}\right)-Y_{-i}-\tau_{i}$. We assume $f$ is continuous and differentiable in all its arguments, and that $g_{i}^{*}>0$ so that the individual will donate at least a small amount to the public good in equilibrium. These assumptions are reasonable, but play a role in the analysis. They are discussed more below.

A number of properties of $f$ are well known. Normality of all goods ensures that the partial derivative of $f_{i}$ with respect to its first argument, denoted $f_{i a}$, is between zero and unity. ${ }^{3}$ As discussed in Andreoni (1989), the warm glow condition ensures that if a dollar is taken from i's income and used to increase $Y_{-i}$, then $g_{i}$ will fall by less than a dollar; this leads to the partial derivative of $f_{i}$ with respect to its second argument, denoted $f_{i e}$, being positive. If one assumes that there is no "crowd in"-that is, a one-dollar increase in $Y_{-i}$ leads to a less-than-one-dollar increase in $Y^{*}$-it follows that $f_{i a}+f_{i e}<1$ and furthermore that $f_{i e}<1$.

\section{B. Diversity}

Consider a mean-preserving spread of the location of individuals in the community, so that $\delta_{i}$ has weakly increased for all individuals. In such a situation, we say the community has become more diverse. We will be interested in how diversity impacts individuals' marginal propensity to donate

\footnotetext{
${ }^{2}$ We thus assume interior solutions in the equilibrium, although we show below that the results where some individuals are at corner solutions are qualitatively similar.

${ }^{3}$ As in Andreoni (1989), the derivative of $f$ with respect to its first argument is denoted $f_{\text {ia }}$ because the first argument of $f$ captures altruistic preferences for the public good. The derivative with respect to the second argument is denoted $f_{i e}$ because the second argument comes from egoistic (or warm-glow) preferences.
} 
disposable income to the public good. Consider an increase in an individual's disposable income, $\omega_{i}-\tau_{i}$, holding $Y_{-i}$ constant. Disposable income grows if endowed income $\omega_{i}$ increases or if the tax $\tau_{i}$ falls.

If endowed income rises, the resulting change in voluntary donations is simply $\frac{\partial g_{i}^{*}}{\partial \omega_{i}}=f_{i a}$. If taxes are reduced, then the resulting change will be: $-\frac{\partial g_{i}^{*}}{\partial \tau_{i}}=1-f_{i e}$. A reduction in $\tau_{i}$ may be viewed differently by the individual than an increase in $\omega_{i}$ because the former also leads to a decline in the government's provision of the public good. In the extreme case of pure altruism, if the government reduces $\tau_{i}$ by one dollar, individual $i$ will simply take the extra dollar of disposable income and contribute it to the public good to maintain equilibrium, and there will be no change in $f$ at all. With a warm glow, however, the tax cut is partly viewed by the individual as increasing income. In the extreme case where individuals give only because of a warm glow, individual $i$ will respond to a tax cut in exactly the same manner as an increase in endowed income, and $1-f_{i e}=f_{i a}$. Notice here that any change which leads to an increase in $f_{i a}$ will therefore lead to a decrease in $f_{i e}$.

We will assume that individuals' marginal propensity to donate disposable income to the public good declines as diversity grows. Thus, as endowed incomes rise we assume the corresponding increase in the donations is smaller in more diverse communities. And if taxes fall, the resulting increase in voluntary donations to the public good is smaller in more diverse communities. The following assumption encapsulates these two effects:

Assumption 1: The marginal propensity to donate disposable income towards the public good is lower in more diverse communities. That is, $1-f_{i e}\left(a, e, \delta_{i}\right)>1-f_{i e}\left(a, e, \delta_{i}^{\prime}\right)$ and $f_{\text {ia }}\left(a, e, \delta_{i}\right)>f_{\text {ia }}\left(a, e, \delta_{i}^{\prime}\right)$, where $\delta_{i}^{\prime}>\delta_{i}$.

The assumption that $1-f_{i e}\left(a, e, \delta_{i}\right)>1-f_{i e}\left(a, e, \delta_{i}^{\prime}\right)$ may be considered an assumption on the impact diversity has upon warm-glow preferences. Essentially, the marginal value of spending a dollar 
on the warm glow is falling as diversity rises. To see this, take the extreme case and suppose people only give because of the warm glow. If the government cuts taxes, the individual views this as an increase in income and he may spend some of this tax cut on the warm glow. As diversity grows, the marginal value of a dollar spent on the warm glow diminishes. Thus the individual's propensity to spend a tax cut on the public good, $-\frac{\partial g_{i}^{*}}{\partial \tau_{i}}=1-f_{i e}$, will fall, or equivalently $f_{i e}$ will increase. An increase in $f_{i e}$ here is thus consistent with a "cooling off" of the warm glow. This would be the case where an individual gives because he likes to be perceived as generous, but as diversity grows the individual cares less about his reputation in the community.

The first inequality in Assumption 1 is relevant only in a model of impure altruism. However the second assumption, that $f_{i a}\left(a, e, \delta_{i}\right)>f_{\text {ia }}\left(a, e, \delta_{i}^{\prime}\right)$ leads to diversity impacting the public good even if there is no warm glow at all. As diversity increases, the individual's marginal valuation of the level of public good in the community falls. Thus if income rises, in a more diverse community the individual will devote a larger share of the new income towards private consumption. ${ }^{4}$ This would be the case where an individual gives (for instance) to charities for the poor because the individual wants there to be less poverty. But as the community grows diverse, the individual cares less about alleviating poverty, and the individual's marginal propensity to donate income towards fighting poverty is reduced.

Generally, it is not possible to use the sign of a cross-partial derivative to obtain the sign of a first derivative. In this case, however, it turns out that either of the inequalities given in Assumption 1 are sufficient to sign $f_{i \delta}$.

Lemma 1: Each inequality in Assumption 1 implies that $f_{i \delta}<0$.

All proofs are given in the appendix. Figure 1 provides intuition for this result; the figure traces out the “Engle curves” for $i$ 's optimal level of $Y$, with $Y_{-i}$ held constant. There are two ways to increase

\footnotetext{
${ }^{4}$ The assumption $f_{i a}\left(a, e, \delta_{i}\right)>f_{i a}\left(a, e, \delta_{i}^{\prime}\right)$ would also have relevance in a model of pure warm glow, however. In that case $1-f_{i e}=f_{i a}$ and so imposing the first inequality in Assumption 1 leads directly to the second inequality holding.
} 
disposable income while holding $Y_{-i}$ constant: increase $\omega$ or decrease $\tau$. Panel A shows that as $\omega$ grows and disposable income rises, the Engle curves for less diverse communities are steeper (which is true by the second inequality in Assumption 1), and since all curves expand from the same point it follows that at any positive level of disposable income, and for any $Y_{-i}$ and $\tau_{i}$, $f$ will be higher for less diverse communities - and thus $f_{i \delta}<0$. Panel B shows that as $\tau$ falls (which corresponds to moving from right to left along the $\mathrm{x}$ axis), the increase in $f$ is steeper in less diverse communities (which is true by the first inequality in Assumption 1), again ensuring that higher levels of $\delta_{i}$ have lower levels of $f_{i}$, all else equal.

The model's assumption that the solution is interior as disposable income goes to zero plays a key role in this result. In the context of Figure 1, interiority ensures that all Engle curves expand from the same point. This assumption would generally be untrue in a model of pure altruism. However, it can be maintained by assuming that no matter how small is disposable income, the individual will be willing to get at least some warm glow by spending money on $g_{i}$. Such an assumption is analogous to Ribar and Wilhelm's (2002) assumption that the joy of giving is "strictly operative."

The fact that $f_{i \delta}$ is negative yields the following proposition:

Proposition 1: Suppose a community grows more diverse so that $\delta_{i}$ increases for all $i$. Then the equilibrium level of the public good will fall.

The model's implication for the relationship between diversity and public-good provision is thus in accordance with prior empirical research—all else equal, more diverse communities have lower levels of public good provision.

3C. Crowd-out

While Assumption 1 has clear implications of how diversity affects the amount of the public good provided in equilibrium, its implications for how diversity affects the strength of warm glow are ambiguous. To see this, consider as a measure of the dominance of warm glow in the model $f_{i a}+f_{i e}$, 
which simply indicates how responsive individual $i$ is to an increase in $Y_{-i}$. We can write $\frac{\partial g_{i}^{*}}{\partial Y_{-i}}=f_{i a}+f_{i e}-1$; higher levels of $f_{i a}+f_{i e}$ thus correspond to a stronger role for warm glow. In the extreme case where giving is driven entirely by the warm glow, $f_{i a}+f_{i e}=1$; an increase in $Y_{-i}$ has no impact on individual's i's decision. Notice that the two inequalities in Assumption 1 show that diversity pushes $f_{i a}+f_{\text {ie }}$ in opposite directions. If diversity works primarily by affecting warm glow, changes in $f_{i e}$ will dominate and diversity will increase the sum $f_{i a}+f_{i e}$. If diversity works primarily through altruistic tastes for the public good, changes in $f_{i a}$ will dominate and $f_{i a}+f_{i e}$ will fall as diversity grows.

To bring this into a discussion of equilibrium outcomes, consider two equilibrium outcomes $\mathrm{A}$ and B, where $\delta^{A}<\delta^{B}$. Let $f_{i e}^{A}=f_{i e}\left(\omega_{i}+Y_{-i}^{A}, Y_{-i}^{A}+\tau_{i}, \delta^{A}\right)$, where $Y_{-i}^{A}=\sum_{j \neq i} g_{j}^{*}+\tau_{j}$ in equilibrium outcome A , and similarly let $f_{i a}^{A}=f_{i a}\left(\omega_{i}+Y_{-i}^{A}, Y_{-i}^{A}+\tau_{i}, \delta^{A}\right)$. Analogous definitions hold for $f_{i e}^{B}$ and $f_{i a}^{B}$. We will use the following definitions to encapsulate diversity's impact on the relevance of warm glow:

Definition: Consider two equilibrium outcomes $A$ and $B$, where $\delta^{A}<\delta^{B}$. We say

(A) Warm glow is increasing with diversity if $f_{i a}^{A}+f_{i e}^{A}<f_{i a}^{B}+f_{i e}^{B}$ for each individual $i$.

(B) Warm glow is decreasing in diversity if $f_{i a}^{A}+f_{i e}^{A}>f_{i a}^{B}+f_{i e}^{B}$ for each individual $i$.

Suppose the government increases taxes and uses the revenue to provide more of the public good.

Without loss of generality suppose the taxes are levied on person 1 . Then let $\frac{\partial Y}{\partial \tau_{1}}$ represent the equilibrium change in the public good in response to this intervention. The following proposition relates the impact of diversity on warm glow to crowd-out:

Proposition 2: Consider two equilibrium outcomes $A$ and B, where $\delta^{A}<\delta^{B}, f_{i a}^{A}>f_{i a}^{B}$, and $f_{i e}^{A}<f_{i e}^{B}$. 
(A) If warm glow is increasing with diversity, then crowd-out will be smaller in the equilibrium with greater diversity. That is, $\frac{\partial Y^{A}}{\partial \tau_{1}}<\frac{\partial Y^{B}}{\partial \tau_{1}}$.

(B) If warm glow is decreasing with diversity, then crowd-out may either be larger or smaller in the equilibrium with greater diversity.

Proposition 2 shows diversity's impact on the public good is ambiguous. If diversity works by "heating up” individuals' warm glows, then all else equal more diverse communities will have less crowd-out than relatively homogeneous communities. Individuals will be relatively unresponsive to changes in the government's provision of the public good, because they do not view the government's provision as substitutable with their own. Intriguingly, in this case diverse communities have the lowest levels of public goods but will be the communities where government intervention is most effective.

If diversity works by "cooling off" the warm glow, however, then the impact of diversity is ambiguous. The ambiguity comes from the fact that the government raises the revenue to provide the public good through taxation, and as the government raises taxes on individual 1 he will unambiguously be less responsive to this crowd-out in a more diverse equilibrium. Other individuals will in this case be more responsive to a change in government provision, and it is unclear in general which effect will dominate.

\section{D. Corner Solutions}

The above ambiguity is resolved if the increased government funds are taken from a non contributor. Until now we have supposed that all individuals give to the public good. Suppose now, however, that individual $n+1$ in the community donates nothing to the public good in equilibrium. Consider an increase in the government's provision of the public good that is financed by taxing this individual. Then we have the following:

Proposition 3 Consider two equilibrium outcomes $A$ and $B$, where $\delta^{A}<\delta^{B}, f_{i a}^{A}>f_{i a}^{B}$, and $f_{i e}^{A}<f_{i e}^{B}$. Suppose the government increases provision of the public good by taxing a non-contributor. Then: 
(A) If warm glow is increasing with diversity, then crowd-out will be smaller in the equilibrium with greater diversity. That is, $\frac{\partial Y^{A}}{\partial \tau_{n+1}}<\frac{\partial Y^{B}}{\partial \tau_{n+1}}$.

(B) If warm glow is decreasing with diversity, then crowd-out will be larger in the equilibrium with greater diversity. That is, $\frac{\partial Y^{A}}{\partial \tau_{n+1}}>\frac{\partial Y^{B}}{\partial \tau_{n+1}}$.

While propositions 2 and 3 are based on the assumption that diversity lowers levels of altruism, it should be clear that a similar ambiguity would hold if the opposite were true and diversity increased altruism. Thus, the basic conflict between altruism and warm glow would hold even in a "hot glow" model where diversity heated up warm glows. The ambiguity of the model also works the other wayfactors which increase (or decrease) the efficacy of government intervention will in general have an ambiguous impact on the level of altruism in a community.

The model here also has implications for Ribar and Wilhelm's argument. As mentioned earlier, Ribar and Wilhelm show that under certain conditions the warm glow effect should dominate individuals' incentives in large communities, and crowd-out should therefore become negligible. But a number of studies find large crowd-out even though the relevant populations are likely quite large (e.g., Payne, 1998; and Hungerman, 2005). If as a community grows its characteristics change, then changes in warm glow may counteract the asymptotic result in their paper. Intuitively, it may not only be the "quantity," but the “quality,” of individuals in a community that matters as a community grows larger.

The model here might also have implications where public goods are jointly provided by two different levels of government, rather than by the government and individuals. Prior research has shown that local governments may be sensitive to community demographics and thus the impact of a centralized government's intervention could vary by local community characteristics. That is, the "flypaper effect" might vary based on local community diversity. I discuss extending this model to flypaper concerns more in the conclusion. 
The theoretical ambiguity outlined by the model suggests that the relationship between diversity and crowd-out is an empirical matter. The next section empirically investigates differences in crowd-out between different homogeneous and diverse communities.

\section{Empirical Evidence}

\section{A. Data}

This section empirically examines how diversity and crowd-out are related in one particular situation. I follow Hungerman (2005) and compare the charitable activities of religious organizations to means-tested government payments. The data on altruistic activities comes from a large dataset on charitable activities undertaken by United Methodist Church (UMC) congregations. This is the third largest denomination in the country; the data consist of roughly 20,000 churches each year, from 1984 to 2000. Adherence is strong in all areas, and congregations are located in most counties $(2,940)$ in the United States. The widespread nature of this denomination will be valuable in this study. The data have not been used in research before.

Table 1 provides some summary statistics for congregations and local community characteristics. Per-member charitable church spending will be the dependent variable in the analysis. Similar to Gruber and Hungerman (2007), this variable captures all spending by a congregation beyond operating expenses such as pastor's salaries, capital expenses, supplies, and utilities. The mean of the variable is fairly large; about \$190 per member (all monetary amounts are in year 2000 dollars), although average total church expenditures (including operating expenses) are considerably larger, about $\$ 500$ per member. To the extent that this variable captures spending on projects unrelated to local means-tested government spending (such as spending on international causes) the resulting estimates will be biased towards zero.

The UMC data contain information on county of location for each community, and the table shows relevant county-level controls included in the regressions. ${ }^{5}$ A number of variables controlling for

\footnotetext{
${ }^{5}$ As in other past research on churches (Pepall et al., 2007; Hungerman 2005) the county is the measure of community used. Hungerman (2007) compares county and census tract measures of communities in an analysis of
} 
economic conditions in a community are included, such as the share of the population made up of impoverished children (a "child" is below the age of 18), unemployment compensation, and the share of households headed by a single female. Following Vigdor (2002), racial shares in levels will be included on the right hand side. A number of variables controlling for the age distribution are also included. County population will be controlled for using a set of 10 dummy variables; one for each population decile. Year dummies will also be included.

The demographic data are taken from the decennial Censuses and are linearly interpolated across years. The SSI and unemployment data, which include state and federal payments, are taken from the Bureau of Economic Analysis (BEA).

The key type of government spending to be used is Supplemental Security Income (SSI) spending. SSI is a national, means-tested program for blind, elderly, and disabled individuals. As of the year 2000 (the end of the period of analysis), SSI was the largest federal means-tested cash-assistance program in the United States (Daly and Burkhauser, 2003).

We will estimate following equation

$$
y_{i c t}=\gamma \operatorname{ssi}_{c t} * \text { diversity }_{c t}+\lambda \text { diversity }_{c t}+\delta s s i_{c t}+X_{i c t} \beta+\theta_{i}+\phi_{t}+\varepsilon_{i c t}
$$

Where $y_{\text {ict }}$ is per-member spending on local charitable activities by congregation $i$ in county $c$ in year $t$, diversity is a measure of a community's diversity, ssi is per-capita county expenditures on SSI, $X_{i c t}$ is a set of church and community specific controls, $\theta_{i}$ is a church fixed effect, $\phi_{t}$ is a year fixed effect, and $\varepsilon_{i c t}$ is noise. The coefficient of interest is $\gamma$, which measures how the relationship between government SSI payments and charitable church activity depends on community diversity.

The measure of diversity used will be the basic race Herfhindahl index, $1-\sum_{j}$ share $_{j}{ }^{2}$, where share $_{j}$ is the share of a county's population that is made up by racial group $j$. (Qualitatively similar results to the ones shown here are obtained by using alternate measures of diversity, such as percent black in a 
community). The index is the standard measure of diversity in the literature (as discussed in Alesina and La Ferrara, 2005) and can be interpreted as the likelihood that two individuals drawn from the same community are of different racial backgrounds. The racial categories used are Asian/Pacific Islander, black, Native American, white and other. While this construction of the index is common in the literature, one may argue that Hispanic should constitute a unique racial group. Appendix Table A1 shows that the results are essentially the same regardless of whether Hispanic is included in the index.

\section{B. Identification.}

If unobserved phenomena cause correlation between government SSI spending and charitable church spending, then the estimates of $\gamma$ and $\delta$ may be biased. To instrument for government spending, the regressions will exploit a 1990 Supreme-Court ruling that mandated an expansion of SSI program to certain groups of low-income children.

Originally, children made up only a small fraction of the SSI caseload. But a Supreme Court decision in the case of Sullivan $v$. Zebley expanded eligibility criteria for children, essentially by mandating that their eligibility criteria be made comparable to the criteria used for adults. The ruling established an Individual Functional Assessment (IFA) of child applicants which could be used to verify that an applicant was disabled. As Daly and Burkhauser explain, "by allowing applicants who did not meet the medical listing [eligibility criteria] to be found disabled if their impairments were severe enough to limit their ability to engage in age-appropriate activities, such as attending school, the IFA lowered the level of severity required for children to be eligible for SSI benefits” (pg 91).

The impact of the Zebley decision on child enrollment in SSI was dramatic. The number of SSI child recipients more than tripled between 1989 and 1995 (Social Security Administration, 2006a). In 1996, more than $\$ 5$ billion was paid in SSI benefits to over a million children (Loprest, 1997). ${ }^{6} \quad$ The population of children on the program is therefore sizeable, and the benefits these children were eligible

\footnotetext{
${ }^{6}$ More than two-thirds of children on SSI qualify because of a mental disorder; the greatest proportion of this group is made up of mentally retarded children. Diseases of the nervous system also make up a sizeable share (about 10 percent) of recipients; see Social Security Administration, (2006b).
} 
for was sizable as well. In 1996, SSI provided up to \$484 in monthly assistance; the median family with a child on SSI had total annual income of about \$14,000 (Loprest, 1997).

Figure 2 shows the growth in average per-capita SSI spending. The solid line depicts average per-capita county SSI payments for churches in the sample across time. There is a slight upward trend in SSI payments prior to the Zebley decision, but a clear and sharp increase in payments afterwards. Moreover, the post 1991 growth of SSI corresponds to a similarly strong increase in the share of SSI recipients who were children. As shown in Figure 3, which is based on SSA data, the percent of SSI recipients below age 18 was essentially flat before the Zebley decision, and grew sharply after that until 1996 (the plateau following 1996 will be discussed more below). Taken together, Figures 2 and 3 illustrate the significant impact that the Zebley decision had on child enrollment in SSI and the SSI program more generally.

It is possible that families affected by this ruling may have responded with changes in adult labor market outcomes, offsetting the financial benefits provided by the program. Also, SSI eligibility may have led to changes in eligibility or take-up of other programs, in particular Medicaid (for which most SSI recipients are categorically eligible). A recent paper by Duggan and Kearney (2005) considers these issues. They find that the net benefits of a family's child enrolling in SSI are substantial—enrollment is associated with a nearly \$2000 increase in total household income over a four month period. They also find a modest impact of SSI enrollment on a child's Medicaid eligibility; this will be discussed more in the next section. They also find that a child's SSI enrollment has little impact on family structure (e.g., parents’ marital status).

States may also have responded to the court ruling by changing the generosity of their own SSI programs. But while states have the ability to administer their own programs supplementing federal SSI payments, “a number of factors minimize the importance of these programs” (Daly and Burkhauser, 2003, pg 97). Many states only supplement SSI payments to small fractions of recipients, such as certain 
recipients living in institutions. ${ }^{7}$ Also, most state supplements make up a small share of total SSI payments, with the federal government's contributions exceeding state supplementation by roughly an order of magnitude (cf. Table 2 in Social Security Administration, 2004). Additionally, most supplemental benefits follow the same rules as federal benefits and are in fact administered by the Federal Government. Furthermore, the regressions include church-level dummies, which would subsume statelevel dummies and thus control for persistent variation in SSI administration across states. All of this suggests that changes in state-level administration of SSI will not significantly affect the analysis.

One might also wonder whether SSI is disproportionately used by minority children, which might lead to the post 1991 expansion being concentrated in high-minority (and also diverse) areas. Data on the racial makeup of children on SSI are difficult to acquire. ${ }^{8}$ However, Scott (1999) provides evidence that as of 1998 about $41 \%$ of the children on SSI where white. This estimate is reasonably close to the Census Bureau's own estimate that 45\% of all impoverished individuals were white in 1999 (Table 6 in Bishaw and Iceland, 2003). One might thus expect the Zebley decision to have similar impacts both in largely white communities and in more diverse communities, all else equal.

Of course, the Census Bureau's estimate also points out that if diverse communities are often high-minority, they might be expected to be poorer than other communities, all else equal, and this may affect charitable church activities. The analysis here responds to this fact in four ways. First, fixed effects are used, which will address persistent economic conditions across communities. Second, a number of controls for economic conditions will be included in the regressions. Third, given the use of fixed effects the identification strategy compares the change in church activity after 1991 in communities with many poor children to other communities. Thus, only a change in the relationship between unobservables and race coincident with the Supreme Court's decision could impact the estimates. Fourth, controls for race will be included in all regressions, and the results shown below are similar if racial controls are removed from the set of regressors. This suggests that a time varying relationship between race and unobservables does not drive the results.

\footnotetext{
${ }^{7}$ Only about 5\% of child SSI recipients live in institutions (Powers, 2002).

${ }^{8}$ See Scott (1999) for a discussion of the difficulties.
} 
The expansion of SSI to children was curtailed to some extent by the 1996 Personal Responsibility and Work Opportunity Reconciliation Act (PRWORA), also known as the 1996 welfare reform. As described by the Social Security Administration (2006a), the welfare reform law ended the use of IFA, changed the way maladaptive behaviors were considered in determining eligibility, and mandated that individuals on SSI turning 18 have their eligibility re-determined. These changes restricted eligibility for children, although the criteria for eligibility were still more lenient than before the Zebley decision.

Normally, one might regard such a law change as valuable for purposes of identification. Indeed, Hungerman (2005) exploits the passage of the 1996 welfare reform law to study crowd-out between means-tested government spending and charitable spending by a group of Presbyterian congregations. However, to study differences in crowd-out between homogeneous and diverse communities, the 1996 reform poses a number of challenges. The law restricted non-citizen access to a number of means-tested programs, including SSI, Medicaid, AFDC (now TANF), and especially Food Stamps. Since highly non-citizen communities are more likely to be diverse than are other communities; the impact of the reform was different in the two types of communities. This complicates comparisons across communities of crowd-out estimates derived from this law; it is hard to say whether resultant differences are from differential changes in altruism or from differential changes in government activity. The results shown below consequently do not use the welfare law for identification. Also, the regressions shown below are robust to removing post-1996 observations from the data, suggesting that the results are not being driven by the welfare reform law.

Finally, there is evidence that congregations_and in particular Methodist congregations—are willing to partner with government programs such as SSI which provide support for disadvantaged or disabled youth and adults. The 1988 Book of Discipline for the United Methodist Church states that "We affirm the responsibility of the Church and society to be in ministry with all persons, including those persons with mentally, physically, and/or psychologically handicapping conditions” (pg 72) (United Methodist Church, 1988a). In 1988, the General Conference of the United Methodist Church considered 
a resolution providing information on the needs of poor children, including information on the needs of poor handicapped children. The resolution stated that United Methodist churches "seek a creative partnership with national government agencies concerned with children, including utilization of federal funds and services” and that "a coordinated ministry that reaches out to join with the health services, mental health and professional community is needed in every local area.” The resolution also directly addresses the potential for crowd-out of local church activities: "the funds from the public sector have been greatly reduced over the past few years; thus there is a need for local churches and annual conferences to advocate for increased funding from the church and the government for these institutional ministries of the church” (pg D-1-7) (United Methodist Church, 1988b)

In sum, the court-mandated expansion of the SSI program created a large and widespread increase in the largest federal means-tested cash-transfer program in the United States. Research suggests that families' strategic responses to SSI's expansion were minimal, and that states' ability to respond to the expansion by altering their own SSI programs was limited. Work also suggests that the expansion did have significant impacts on the resources available to families with children newly eligible for SSI. There is also evidence that Methodist congregations care about the wellbeing of needy children and that Methodists were responsive to funds from "the public sector" that supplemented the ministries of the church for the poor and disabled. All of this suggests that the identification strategy is sound.

\section{C. Results}

This subsection reports estimates from 2SLS regressions where the key endogenous variables are per-capita SSI spending and per-capita SSI spending interacted with a racial Herfindahl index. Two instruments are used to identify these variables. The first instrument is an interaction variable between the share of the population made up of impoverished children times a dummy that equals unity from 1991 onwards. The instrument thus captures the fact that per-capita SSI spending will rise relatively more in communities with large shares of poor children after the court ruling. The second instrument is a triple interaction between (a) the share of the population made up of impoverished children (b) a post-1990 dummy and (c) the race Herfindahl index. 
Figure 4 provides a simple graphical illustration of the regression results to come. The figure depicts two lowess-curve estimates of the relationship between (a) the fraction of a county's population made up of poor individuals under 18 and (b) the difference in average charitable spending in each county after 1991 relative to before 1991. One curve is for counties with below-average Herfindahl index values (low-diversity counties); the other curve is for counties with above-average values. Consistent with crowd-out, both curves slope down, showing less spending growth in areas where the Zebley decision had a strong impact. But the low diversity curve is consistently steeper, indicating a larger effect in these counties.

The regression results will indicate whether the intuition of the figure holds up to a more rigorous analysis. Table 2 shows the basic regression results; all regressions report robust standard errors clustered by county and the year 1990 (when the Supreme Court decision was made) is dropped from the analysis. The uninteracted SSI term is negative and significant, suggesting that as per-capita SSI spending increases charitable church spending falls. The coefficient implies that a one-dollar increase in SSI spending will crowd-out about 52 cents of per-member charitable church spending in a county with zero diversity. For the average county (whose index is 0.23 ), the estimated response is 31 cents—a result that is reasonably close to the baseline estimate in Hungerman (2005), a paper using different data and a different identification strategy. Table 7.A4 of the Social Security Administration (1997) shows that from 1991 to 1995 annual SSI spending was on average \$7 billion above its 1990 level. If the UMC congregation estimates can be taken as representative of other religious adherents (which make up about half the population) a 31-cent member response is similar to a 15-cent per-capita response. Thus, the rise in SSI spending over this period would have crowded-out roughly a billion dollars annually in charitable church activity.

However, the interaction between SSI spending and the Herfindahl index is positive and significant, suggesting that high values of the index (that is, diverse counties) have crowd-out closer to zero. The largest value obtained by the index in the sample is 0.7 ; thus for the most diverse communities the point estimate is wrong signed and close to zero. The regression indicates that crowd-out is being 
driven only by relatively homogeneous communities. Turning to the other coefficients, the uninteracted race Herfindahl is negative, suggesting that charitable activity is lower in more diverse communities, all else equal. Church activity is higher in communities with large shares of poor children, and church activity is higher in areas with relatively large shares of children or the elderly. Consistent with prior research, the estimates show charitable activities are lower in larger congregations.

The next two columns show the first stage regressions. The regression on SSI spending shows that both instruments are clearly significant, with the triple interaction term negative. The simpleinteraction instrument suggests that if a county population's share of impoverished children increased by a standard deviation (0.025), then that county would consequently expect about a \$25 larger increase in post-1990 per-capita SSI spending, all else equal. The triple interaction term says this post-1990 increase would be about \$3.65 smaller if the county’s Herfindahl index were a standard deviation larger (the standard deviation for the index is 0.18). Thus, SSI spending grew in areas with relatively large shares of poor children following the Zebley decision, although this growth was slightly smaller in more diverse areas. A Wald test that the sum of the two instruments equals zero can be rejected at the one-percent level; and even if the Herfindahl index were to equal unity, implying infinite diversity, the two instruments together still suggest a positive and economically significant impact of the Zebley decision on SSI spending. The final column shows the first-stage regression on the interaction of SSI spending and the race Herfindahl. Again, both instruments are significant and now both are positive.

Table 2 therefore suggests that crowd-out does vary by community diversity, with diverse communities being more amenable to government intervention than are other communities. The difference in crowd-out between the two communities is economically significant; the average community has reasonably large crowd-out while the most diverse communities have no crowd-out at all.

Table 3 presents some robustness tests of the basic 2SLS regression. The first column is taken from Table 2. The next column reports an OLS regression; the uninteracted coefficient on SSI spending is much smaller than before and the interacted coefficient is slightly smaller than before. The positive bias of OLS is consistent with a story where unobservables (such as community neediness) lead to a 
spurious positive correlation in church charitable spending and SSI. However, the size of the interacted coefficient suggests that this bias is not significantly different across different types of communities.

The third column of Table 3 does not include church (or county) fixed effects; the variation in SSI and race driving these results is therefore quite different than the variation driving the baseline estimates. The coefficients are strikingly similar to those in the baseline regression; the result provides strong evidence of the quality of the identification strategy. The last column uses per-member church operating expenses as the key dependent variable (these include for example payments on upkeep, insurance, supplies and utilities). The uninteracted coefficient is positive and marginally significant; consistent with a story where churches may increase current expenses when their charitable spending has been crowded-out. The uninteracted coefficient is much smaller than before and is insignificant.

As discussed in the prior subsection, one potential concern about this result is that it excludes other government spending that might also crowd-out church spending. Table 4 addresses this and other concerns. The first column repeats the basic regression of Table 2, except that other means-tested percapita government spending, including spending on Medicaid, Food Stamps, and AFDC/TANF, are included on the right-and side as a control (the spending data for these programs come from the BEA). The estimated coefficients are extremely similar to before.

The second column uses all four means-tested programs together as the relevant measure of government spending. Again the qualitative result is the same-as spending on SSI, Medicaid, Food Stamps, and AFDC/TANF rises, charitable church spending falls, but only in relatively homogeneous communities. The decrease in the coefficients' size between this result and the baseline result in Table 2 is driven by an increase in the size of the coefficients on the instruments in the first stage (since the reduced-form regression is the same). The increase in the instrument size suggests that the increase in SSI from the Zebley decision increased spending in these other programs, which is not surprising since SSI eligibility is in some cases mechanically linked to eligibility for Medicaid and Food Stamps. In particular, the sizeable increase in the first-stage coefficients on the instruments is likely driven by Medicaid; a program which is both relatively large and relatively less likely to substitute for church 
activities than are the other three programs. The third column in Table 4 repeats the regression of column 2 but this time government spending is only SSI, AFDC/TANF, and Food Stamps. The result is once more extremely close to the original estimation.

One might be concerned that the interacted coefficients estimated thus far have been affected by constraining the relationship between diversity and crowd-out to be linear with respect to the Herfindahl index. A solution to this would be to create dummy variables for different levels of diversity, and interact them with government spending. The last three regressions shown in Table 4 interact government spending with two dummy variables measuring diversity: the first dummy equals unity if a county’s Herfindahl index is greater than 0.2 and less than 0.4 (these communities are "in-between” diversity and homogeneity) and the second dummy equals unity for communities with an index value above 0.4 (diverse communities). (The regressions also include uninteracted dummies for in-between and diverse counties.) A covariate for government spending without any interactions is also included; its coefficient thus captures crowd-out in racially homogeneous communities. ${ }^{9}$

Figure 5 shows a histogram of the distribution of diversity across churches in the sample. On top of the histogram is smoothed-out kernel estimate of the density of diversity. There is a spike to the left, representing a large share of observations in relatively homogeneous communities. There is also a small but long right tail. The two dummy variables constructed here each represent about a quarter of the sample, with the "in-between" dummy making up the $3^{\text {rd }}$ quartile and the diverse dummy making up the $4^{\text {th }}$ quartile. Given the spike to the left of this figure, combining the first two quartiles together seems intuitive. $^{10}$

As seen in Table 4, the results are qualitatively similar in this case, regardless of whether only SSI, all types of means-tested spending, or all types of means-tested spending but Medicaid are included. The coefficient for the in-between dummy*government spending is in all cases positive and significant,

\footnotetext{
${ }^{9}$ There are three excluded instruments for these 2SLS regressions. The first instrument is the standard one, share of poor children in a county times a post 1990 dummy. The second instrument is an interaction of the standard instrument and a dummy for whether a county is an "in-between" community. The final instrument is an interaction of the standard instrument and a dummy for whether a county is a diverse community.

${ }^{10}$ Indeed, breaking the first two quartiles apart does not qualitatively change these estimates.
} 
suggesting that moderately homogeneous counties have less crowd-out than the most homogeneous communities and the difference between the two types of counties is significant. The interaction with the heterogeneous dummy is even more positive and significant, suggesting even less crowd-out in the most heterogeneous communities. The size of the coefficients is also economically significant. Extrapolating to other denominations, the estimates in the last column of Table 4 suggest 20 cents on the dollar crowdout in homogeneous communities but only 5 cents on the dollar in diverse communities. For each of the last three regressions, a Wald test that the three coefficients are equal can be rejected. ${ }^{11}$ Overall, these results again suggest that crowd-out is smaller-and close to zero-in diverse communities.

The results in Table 4 constrain all the coefficients besides government spending to be the same across homogeneous and diverse communities. It may be the case that these coefficients are in reality different across different communities, and the results from Table 4 are consequently biased. To address this concern, Table 5 repeats the regression from Table 4, but now each sample-homogeneous counties, in-between counties, and heterogeneous counties—is regressed separately.

The first row of the table shows the 2SLS results; each coefficient is from a 2SLS regression on charitable church spending. Homogeneous counties show clear crowd-out, the magnitude is the same as in Table 4. The point estimate for in-between counties is similar and slightly smaller in absolute value. The coefficient for heterogeneous counties is much smaller and insignificant. Again, the results suggest that crowd-out is driven by homogeneous and somewhat homogeneous counties.

Are these results driven by the first stage regressions? If the expansion of SSI mattered only in homogeneous counties, then an insignificant first-stage coefficient for in-between counties and a wrongsigned first stage for heterogeneous counties could explain the 2SLS results. But the next row of Table 5 shows that this is not the case. This row shows the coefficient for the instrument from first stage regressions for each sample. While the coefficient is largest for homogeneous counties, the first stage is reasonably sized and very significant for all of the samples. The third row of the table shows the reducedform estimates, clearly depicting a steady decline in church reaction to communities with large shares of

\footnotetext{
${ }^{11}$ The table also shows that Wald tests can reject that the coefficient on the spending*in-between dummy equals the coefficient on the spending*diverse dummy in each regression.
} 
poor children after 1991. Together, the results in rows two and three show that the 2SLS estimates are not simply being driven by differences in the first stage. The last three rows of the table repeat the robustness tests from Table 4. Adding other means-tested spending to the right-hand side, using all means-tested spending as the regressor of interest, or using all spending but Medicaid does not change the results.

Overall then, the results here suggest that government spending during this period had a reasonably large crowd-out effect on church spending. However, the results are quite different in homogeneous versus diverse communities, with crowd-out being driven only by homogeneous and somewhat homogeneous counties and not by diverse counties.

\section{Conclusions}

This paper explores whether governments can counteract diversity's impact on altruistic behavior; the findings show that, with regards to the particular policy change studied here, diverse communities were significantly more amenable to government expansion than were homogeneous communities. The estimates here of crowd-out for the average community are reasonably large, and show a sizable disparity in crowd-out between homogeneous and diverse communities. Some other crowd-out studies, such as Payne (1998), also find sizeable crowd-out estimates; crowd-out in those situations might also reflect significant differences across communities.

A key result of this study is that crowd-out can vary by community characteristics, a concept which has been overlooked by most prior work despite the significant empirical differences in crowd-out that are manifest in the literature. While this paper focused on the relationship between crowd-out and diversity, it should be clear that the basic idea of the model could be applied to any factors affecting incentives to voluntarily provide public goods. This work on crowd-out could also help shed light on whether the relative importance of warm-glow incentives over altruistic incentives changes in different situations, an issue raised by Harbaugh, Mayr, and Burghart (2007). Whether other phenomena besides diversity play salient roles in determining crowd-out remains to be seen. 
A second key result of this study is that crowd-out may involve issues of equity, and not just efficiency: similarly-implemented policies can lead to different levels of public goods across communities. Given the size of the coefficients here, it seems likely that variation in crowd-out could lead to economically significant discrepancies in the provision of many different public goods across different communities. A serious analysis of the welfare effects of inequitable crowd-out would need to carefully consider how social welfare is best modeled in the presence of a warm glow; a topic for which there is little consensus (cf. Diamond, 2006). Developing an appropriate methodology for studying the equity implications of crowd-out is an important topic for future research.

Moreover, the (non-experimental) crowd-out literature has for some time focused on the question of whether crowd-out is one-for-one. It is reasonable at this point to conclude that in almost all circumstances crowd-out is not one-for-one, and there is significant empirical and theoretical evidence at this point showing that the models related to Warr (1982) give unreliable predictions. Hopefully the work of this paper shows that empirical variation in crowd-out and the conceptual challenges of studying efficiency and equity in the warm-glow model constitute important unresolved issues in the literature.

Finally, as discussed in the theoretical section, this study may have implications for work in other areas. Steinberg (1991) notes that there are theoretical connections between the crowd-out literature and the literature on the flypaper effect. The model as presented here, however, takes government intervention as exogenous. While such an assumption is consistent with past crowd-out work and is sensible here given the focus of the empirical section, endogenous government decisions often play an important role in flypaper effect stories, as Knight (2002) argues. Whether community characteristics lead to variation in the effect of inter-government transfers remains to be seen. 


\section{Appendix}

\section{Proof of Lemma 1:}

Consider a decrease in endowed income $\omega_{i}$ toward $\tau_{i}$, so that disposable income falls towards zero. By the budget constraint given in (2) and by the continuity of $f$, as $\omega_{i}$ approaches $\tau_{i}$ it must be the case that voluntary donations converge to zero. Thus, for a given $Y_{-i}+\tau_{i}$, as $\omega_{i}+Y_{-i}$ falls towards $\tau_{i}+Y_{-i}$, i's chosen level of the public good falls to $Y_{-i}+\tau_{i}$. Then for any given levels of $Y_{-i}$, $\tau_{i}$, and $\delta_{i}, \lim _{x \rightarrow \tau_{i}+Y_{-i}^{+}} f_{i}\left(x, Y_{-i}+\tau_{i}, \delta\right)=\tau_{i}+Y_{-i}$. It follows that

$$
f_{i}\left(\omega_{i}+Y_{-i}, Y_{-i}+\tau_{i}, \delta\right)=\int_{\tau_{i}+Y_{-i}}^{\omega_{i}+Y_{-i}} f_{i a}\left(a, Y_{-i}+\tau_{i}, \delta\right) d a-\left(Y_{-i}+\tau_{i}\right)
$$

Suppose $\delta^{\prime}>\delta$. From (A1) we can write $f_{i}\left(\omega_{i}+Y_{-i}, Y_{-i}+\tau_{i}, \delta\right)-f_{i}\left(\omega_{i}+Y_{-i}, Y_{-i}+\tau_{i}, \delta^{\prime}\right)$ as

$$
\int_{\tau_{i}+Y_{-i}}^{\omega_{i}+Y_{-i}} f_{i a}\left(a, Y_{-i}+\tau_{i}, \delta\right) d a-\int_{\tau_{i}+Y_{-i}}^{\omega_{i}+Y_{-i}} f_{i a}\left(a, Y_{-i}+\tau_{i}, \delta^{\prime}\right) d a
$$

where the terms $\left(Y_{-i}+\tau_{i}\right)$ in (A1) cancel out. The two integrals in (A2) are over the same interval, and each function $f_{i a}$ is positive. It follows by the second inequality in Assumption 1 that the expression in (A2) is positive. Thus as $\delta$ increases, all else constant, $f_{i}$ falls. By the assumption of differentiability we have that $f_{i \delta}<0$.

Consider next an increase in $\tau_{i}$ towards its upper limit of $\omega_{i}$, so that disposable income again falls towards zero. Again by (2) and by the continuity of $f$ it must be the case that voluntary donations converge to zero. Thus for a given $\omega_{i}+Y_{-i}$, as $\tau_{i}+Y_{-i}$ rises towards $\omega_{i}+Y_{-i}$, i's chosen level of the public good rises to $\omega_{i}+Y_{-i}$. It follows that for any given levels of $Y_{-i}, \omega_{i}$, and $\delta_{i}$,

$$
\begin{aligned}
& \lim _{x \rightarrow \omega_{i}+Y_{-i}^{-}} f_{i}\left(\omega_{i}+Y_{-i}, x, \delta\right)=\omega_{i}+Y_{-i} \text {. Thus } \\
& \qquad f_{i}\left(\omega_{i}+Y_{-i}, Y_{-i}+\tau_{i}, \delta\right)=\left(\omega_{i}+Y_{-i}\right)-\int_{\tau_{i}+Y_{-i}}^{\omega_{i}+Y_{-i}} f_{i e}\left(\omega_{i}+Y_{-i}, e, \delta\right) d e .
\end{aligned}
$$

Again let $\delta^{\prime}>\delta$. From (A3) we can write $f_{i}\left(\omega_{i}+Y_{-i}, Y_{-i}+\tau_{i}, \delta\right)-f_{i}\left(\omega_{i}+Y_{-i}, Y_{-i}+\tau_{i}, \delta^{\prime}\right)$ as

$$
\int_{\tau_{i}+Y_{-i}}^{\omega_{i}+Y_{-i}} f_{i e}\left(\omega_{i}+Y_{-i}, e, \delta^{\prime}\right) d e-\int_{\tau_{i}+Y_{-i}}^{\omega_{i}+Y_{-i}} f_{i e}\left(\omega_{i}+Y_{-i}, e, \delta\right) d e
$$

By the first inequality in Assumption 1 the expression in (A4) is positive. Thus as $\delta$ increases, all else constant, again $f_{i}$ falls. Thus again we have that $f_{i \delta}<0$. 


\section{Proof of Proposition 1:}

Let $y_{i}=g_{i}+\tau_{i}=f_{i}\left(\omega_{i}+Y_{-i}, Y_{-i}+\tau_{i}, \delta_{i}\right)-Y_{-i}$. Totally differentiate individual i's donation function $y_{i}$ :

$$
d y_{i}^{*}=f_{i a} d Y_{-i}+f_{i e} d Y_{-i}+f_{i \delta} d \delta-d Y_{-i}
$$

Using the fact that $d Y_{-i}=d Y-d y_{i}$, solving for $d y_{i}^{*}$ yields

$$
d y_{i}^{*}=\frac{f_{i a}+f_{i e}-1}{f_{i a}+f_{i e}} d Y+\frac{f_{i \delta} d \delta}{f_{i a}+f_{i e}} .
$$

Adding up over all individuals and solving for $d Y$ shows:

$$
\frac{d Y}{d \delta}=\left(1-\sum_{i=1}^{n} \frac{f_{i a}+f_{i e}-1}{f_{i a}+f_{i e}}\right)^{-1}\left(\sum_{i=1}^{n} \frac{f_{i \delta}}{f_{i a}+f_{i e}}\right) .
$$

The terms summed in the rightmost set of parentheses all have a negative numerator and a positive denominator. The expression in the left set of parentheses can be rewritten $\left(1-n+\sum_{i=1}^{n} \frac{1}{f_{i a}+f_{i e}}\right)^{-1}$, but $\frac{1}{f_{i a}+f_{i e}}>1$ for all $i$ since $f_{i a}+f_{i e}<1$. Thus $\frac{d Y}{d \delta}<0$.

\section{Proof of Proposition 2:}

Define $y_{i}$ as in proposition 1; differentiating person 1's donation function $y_{1}$ yields:

$$
d y_{1}^{*}=f_{1 a} d Y_{-1}+f_{1 e}\left(d Y_{-1}+d \tau_{1}\right)-d Y_{-1}
$$

Substituting $d Y_{-1}=d Y-d y_{1}^{*}$, solving for $d y_{1}^{*}$ yields

$$
d y_{1}^{*}=\frac{f_{1 a}+f_{1 e}-1}{f_{1 a}+f_{1 e}} d Y+\left(1-\alpha_{1}\right) d \tau_{1}
$$

where $\alpha_{1}=f_{1 a} /\left(f_{1 a}+f_{1 e}\right)$. Solving out for all other individuals (holding their taxes constant) and adding the responses of individual 1 to the $(n-1)$ other individuals shows:

$$
\frac{d Y}{d \tau_{1}}=\left(1-\sum_{i=1}^{n} \frac{f_{i a}+f_{i e}-1}{f_{i a}+f_{i e}}\right)^{-1}\left(1-\alpha_{1}\right)=c\left(1-\alpha_{1}\right) .
$$

Consider case (A) in the proposition. Since $f_{i a}^{A}>f_{i a}^{B}$ and by the assumption that warm glow is increasing in diversity it follows that $\alpha_{1}^{A}>\alpha_{1}^{B}$. Looking at the first term, $c$, in (A5), we can again write 
this term as $\left(1-n+\sum_{i=1}^{n} \frac{1}{f_{i a}+f_{i e}}\right)^{-1}$. Since by assumption $f_{i a}^{A}+f_{i e}^{A}<f_{i a}^{B}+f_{i e}^{B}$, it follows that $c^{A}<c^{B} .{ }^{12}$ Thus $\frac{d Y^{A}}{d \tau_{1}}=c^{A}\left(1-\alpha_{1}^{A}\right)<c^{B}\left(1-\alpha_{1}^{B}\right)=\frac{d Y^{B}}{d \tau_{1}}$.

In case (B) $c^{A}>c^{B}$, but $\alpha_{1}^{A}>\alpha_{1}^{B}$. Thus it is unclear whether $c^{A}\left(1-\alpha_{1}^{A}\right)$ is greater or less than $c^{B}\left(1-\alpha_{1}^{B}\right)$. $\square$

Proof of Proposition 3.

Using the exact method used in the proof of proposition 2 we have $\frac{d Y}{d \tau_{n+1}}=\left(1-\sum_{i=1}^{n} \frac{f_{i a}+f_{i e}-1}{f_{i a}+f_{i e}}\right)^{-1}\left(1-\alpha_{n+1}\right)$. However, as discussed in Andreoni (1989), if the individual donates nothing it follows that $\alpha_{n+1}=0$ and $\frac{d Y}{d \tau_{n+1}}=c$, where $c$ is defined as in (A5). It follows for case (A) that $c^{A}<c^{B}$ as before. Additionally, for case (B) it follows that $c^{A}>c^{B}$. $\square$

12 To see this, rewrite $c$ as $\left(1-n+\sum_{i=1}^{n} \frac{1}{\theta_{i}}\right)^{-1}$, where $\theta_{i}=f_{i a}+f_{i e}$. Then for any individual $k$, $\frac{d c}{d \theta_{k}}=c^{2}\left(\frac{1}{\theta_{k}^{2}}\right)>0$. Thus as $f_{i a}+f_{i e}$ increases for all $i, c$ will increase. 


\section{References}

Alesina, Alberto, and Eliana La Ferrara (2000) “Participation in Heterogeneous Communities,” Quarterly Journal of Economics August, 847-903.

Alesina, Alberto, and Eliana La Ferrara (2005) “Ethnic Diversity and Economic Performance," Journal of Economic Literature 43, 762-800.

Alesina, A., R. Baqir, and W. Easterly (1999) "Public Goods and Ethnic Divisions," Quarterly Journal of Economics, November, 1243-1284.

Alesina, A., R. Baqir, and C. Hoxby (2004) "Political Jurisdiction in Heterogeneous Communities," Journal of Political Economy, 112, 348-396.

Andreoni, James (1989) "Giving with Impure Altruism: Applications to Charity and Ricardian Equivalence" Journal of Political Economy 97, 1447-1458.

Bénabou, Roland and Jean Tirole (2006) "Incentives and Prosocial Behavior," American Economic Review 96, 1652-1678.

Bishaw, Alemayehu and John Iceland (2003) Poverty: 1999. Census Brief published by the U.S. Census Bureau.

Cornes, Richard and Todd Sandler (1999) The Theory of Externalities, Public Goods, and Club Goods. Cambridge University Press.

Cornes, Richard and Todd Sandler (1994) "The Comparative Static Properties of the Impure Public Good Model," Journal of Public Economics 54, 403-421.

Costa, Dora L. and Matthew E. Kahn (2003a) “Understanding the American Decline in Social Capital,” Kyklos 56 17-46.

Costa, Dora L. and Matthew E. Kahn (2003b) “Cowards and Heroes: Group Loyalty in the American Civil War," Quarterly Journal of Economics May, 519-548.

Daly, Mary C. and Richard V. Burkhauser (2003) “The Supplemental Security Income Program,” in Means-Tested Programs in the United States, Robert Moffit (ed.). National Bureau of Economic Research and University of Chicago Press: Chicago, IL.

Diamond, Peter (2006) "Optimal Tax Treatment of Private Contributions for Public Goods with and without Warm Glow Preferences” Journal of Public Economics 90, 897-919.

Duggan, Mark and Melissa Schettini Kearney (2005) "The Impact of Child SSI Enrollment on Household Outcomes: Evidence from the Survey of Income and Program Participation,” NBER working paper 11568.

Eckel, Catherine C., and Philip J. Grossman (1996) "Altruism in Anonymous Dictator Games," Games and Economic Behavior 16, 181-191.

Fong, Christina M. (2006) "Evidence from an Experiment on Charity to Welfare Recipients: Reciprocity, Altruism, and the Empathic Responsiveness Hypothesis" Working paper.

Fong, Christina M., and Erzo F.P. Luttmer (2007) "Race and Giving to Hurricane Katrina Victims: Experimental Evidence," Working paper.

Glazer, Amihai, and Kai A. Konrad (1996) “A Signaling Explanation for Charity,” American Economic Review 86, 1019-1028.

Gruber, J. and D. Hungerman (2007) “Faith-Based Charity and Crowd Out during the Great Depression,” Journal of Public Economics, 91, 1043-1069.

Harbaugh, William T. (1998a) "The Prestige Motive for Making Charitable Transfers," American Economic Review 88, 277-282.

Harbaugh, William T. (1998b) "What do Donations Buy? A Model of Philanthropy based on Prestige and Warm Glow,” Journal of Public Economics 67, 269-284.

Harbaugh, William T., Ulrich Mayr, and Daniel R. Burghart (2007) "Natural Responses to Taxation and Voluntary Giving Reveal Motives for Charitable Donations,” Science 316, 1622-1625.

Hoffman, Elizabeth, Kevin McCabe, and Vernon L. Smith (1996) "Social Distance and Other-Regarding Behavior in Dictator Games,” American Economic Review 86, 653-660.

Hollander (1990) “”'A Social Exchange Approach to Voluntary Cooperation,” American Economic Review 80, 11571167.

Hungerman, Daniel M. (2007) “Race and Charitable Church Activity,” Working Paper.

Hungerman, Daniel M. (2005). "Are Church and State Substitutes? Evidence from the 1996 Welfare Reform," Journal of Public Economics 89, 2245-2267.

Khanna, Jyoti, and Todd Sandler, (2000). Partners in Giving: The Crowding-In Effects of UK Government Grants. European Economic Review 44, 1543-1556. 
Kingma, Bruce. (1989). An Accurate Measurement of the Crowd-Out Effect, Income Effect, and Price Effect for Charitable Contributions. Journal of Political Economy 97, 1197-1207.

Knight, Brian (2002) "Endogenous Federal Grants and Crowd-out of State Government Spending: Theory and Evidence from the Federal Highway Aid Program,” American Economic Review 92, 71-92.

Loprest, Pamela J. (1997) "Supplemental Security Income for Children with Disabilities," published by the Urban Institute in series, "Issues and Options for States," No. A-10.

Luttmer, Erzo F.P. (2001) “Group Loyalty and the Taste for Redistribution,” Journal of Political Economy 109, 500528.

Macculloch, Robert (2005) "Income Inequality and the Taste for Revolution," Journal of Law and Economics 48, 93-123.

Miguel, Edward, and Mary Kay Gugerty (2005) “Ethnic Diversity, Social Sanctions, and Public Goods in Kenya,” Journal of Public Economics 89, 2325-2368.

Okten, Cagla and Una Okonkwo Osili (2004) "Contributions in Heterogeneous Communities: Evidence from Indonesia,” Journal of Population Economics 17, 603-626.

Payne, Abigail A. (1998). "Does the Government Crowd-out Private Donations? New Evidence from a Sample of Non-profit Firms” Journal of Public Economics 69, 323-345.

Pepall, Lynne, Dan Richards, John Straub, and Michael DeBartolo (2007) "Crowding out and Competition in the Religious Marketplace,” Working Paper.

Poterba, J. (1997) "Demographic Structure and the Political Economy of Public Education,” Journal of Policy Analysis and Management, 16(1), 48-66.

Powers, Elizabeth T. (2002) "Who are the SSI-Child Beneficiaries? A Closer Look using Social Security Administrative Records and Public-Use Survey Data” Disability Research Institute Final Technical Report.

Ribar, David C., and Mark O. Wilhelm "Altruistic and Joy-of-Giving Motivations in Charitable Behavior," Journal of Political Economy 110, 425-457

Romano, Richard, and Huseyin Yildirim (2001) "Why Charities Announce Donations: A Positive Perspective," Journal of Public Economics 81, 423-447.

Saunders, Shauna (2005) The Case for the National Endowment for the Arts. PhD Dissertation, Duke University.

Scott, Charles G. (1999) "Identifying the Race or Ethnicity of SSI Recipients," Social Security Bulletin 62, 9-20.

Social Security Administration (1997) Annual Statistical Supplement to the Social Security Bulletin. Office of Research, Evaluation, and Statistics

Social Security Administration (2004) SSI Annual Statistical Report, 2004. Office of Policy and Office of Research, Evaluation, and Statistics

Social Security Administration (2006a) "Trends in the Social Security and Supplemental Security Income Disability Programs,” SSA Publication No 13-11831

Social Security Administration (2006b) “Children Receiving SSI, 2005” SSA Publication No 13-11830.

Steinberg, Richard. (1991). Does Government Spending Crowd-out Donations? Interpreting the Evidence. Annals of Public and Cooperative Economics 62, 591-617.

Straub, John and Sonia Manzoor (2005) "The Robustness of Kingma's Crowd-out Estimate: Evidence from Contributions to Public Radio,” Public Choice 123, 463-476.

United Methodist Church (1988a) The Book of Discipline of the United Methodist Church. The United Methodist Publishing House: Nashville.

United Methodist Church (1988b) "Supportive Policies for Families with Children," Position Statement proposed for the Book of Resolutions at the 1988 General Conference of the United Methodist Church, recorded in the Daily Christian Advocate, February 25, 1988, D-1-6 toD-1-8.

Vigdor, J. (2004) "Community Composition and Collective Action: Analyzing Initial Mail Response to the 2000 Census," Review of Economics and Statistics, 86, 303-312.

Warr, P.G. (1982) “Pareto Optimal Redistribution and Private Charity,” Journal of Public Economics, 19, 131-138. 


\section{Figure 1}

\section{Panel A:}

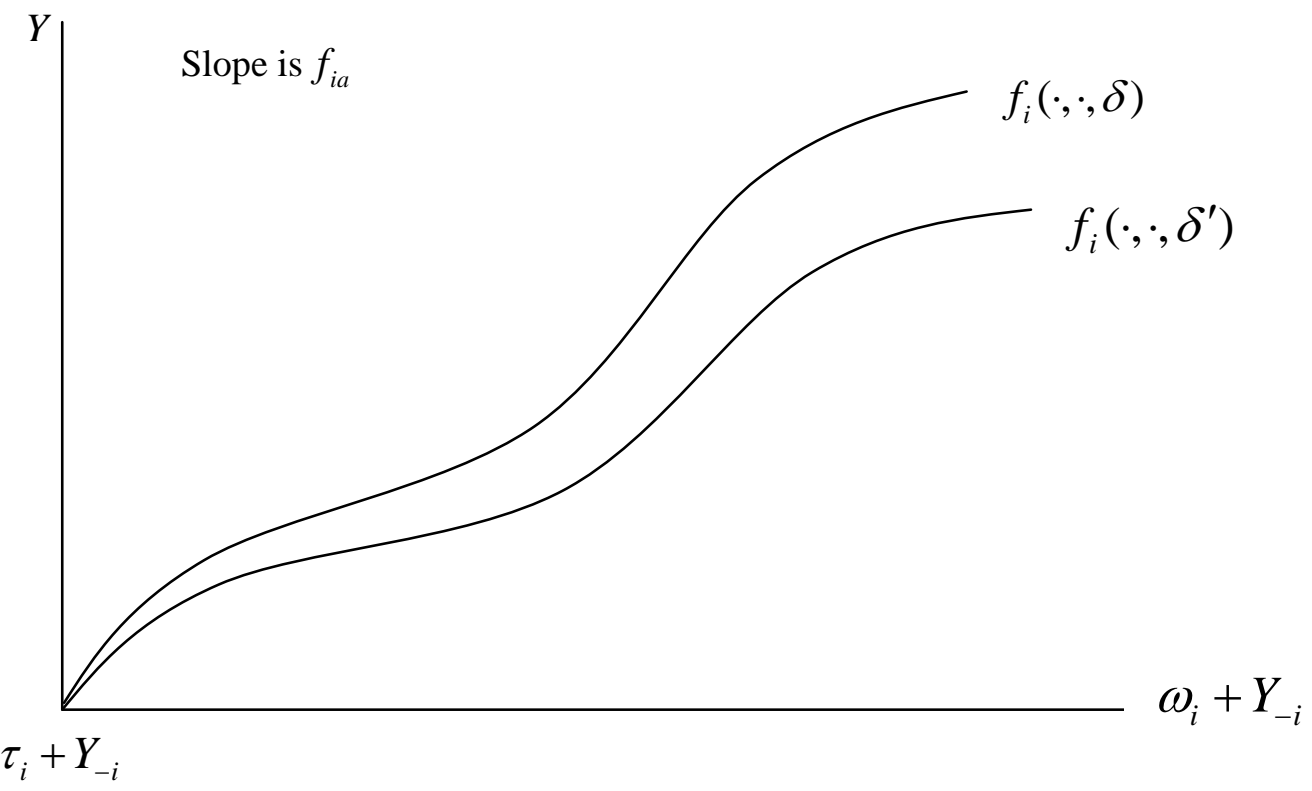

\section{Panel B:}

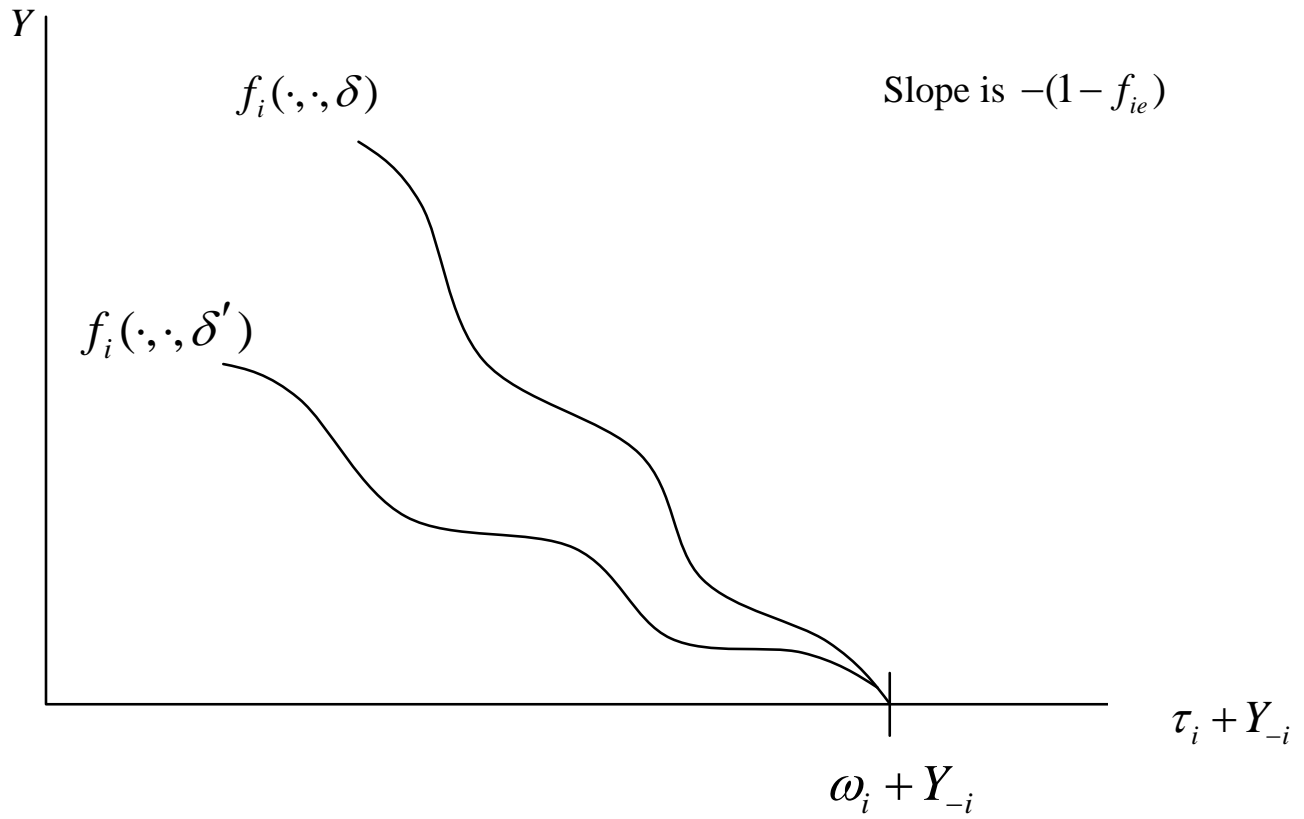

In Panel A, endowed income is rising along the $\mathrm{x}$ axis. In Panel $\mathrm{B}$, lump sum taxes are rising along the $\mathrm{x}$ axis. Each panel shows "Engle curves" for how the optimal choice of $Y$ changes as disposable income changes. In both pictures $\delta^{\prime}>\delta$. 
Figure 2: Per Capita SSI Spending in the Regression Sample by Year

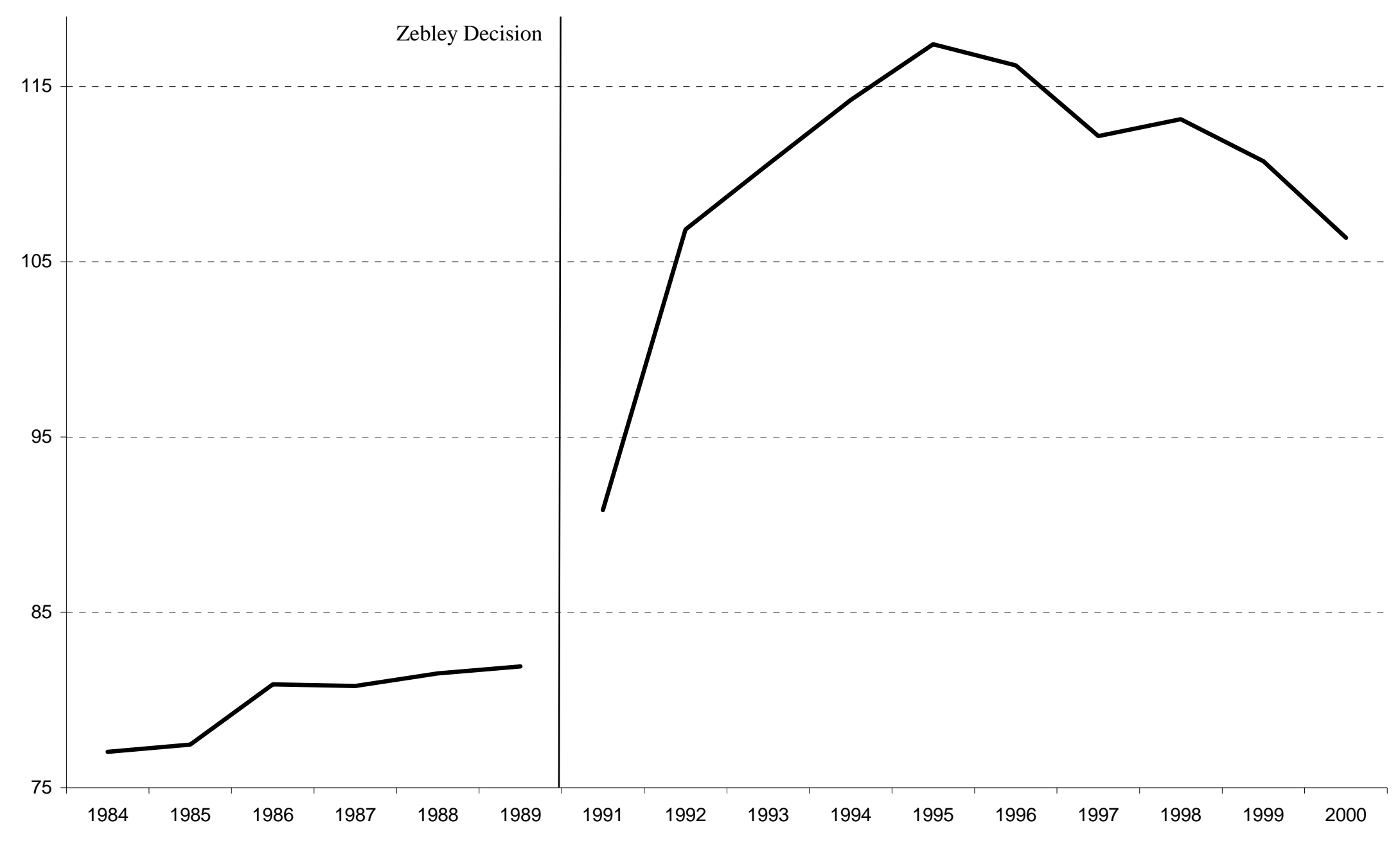

Graph shows average county per-capita spending on SSI for the regression Sample. Spending is in year 2000 dollars. 
Figure 3: Percent of SSI Recipients under the Age of 18

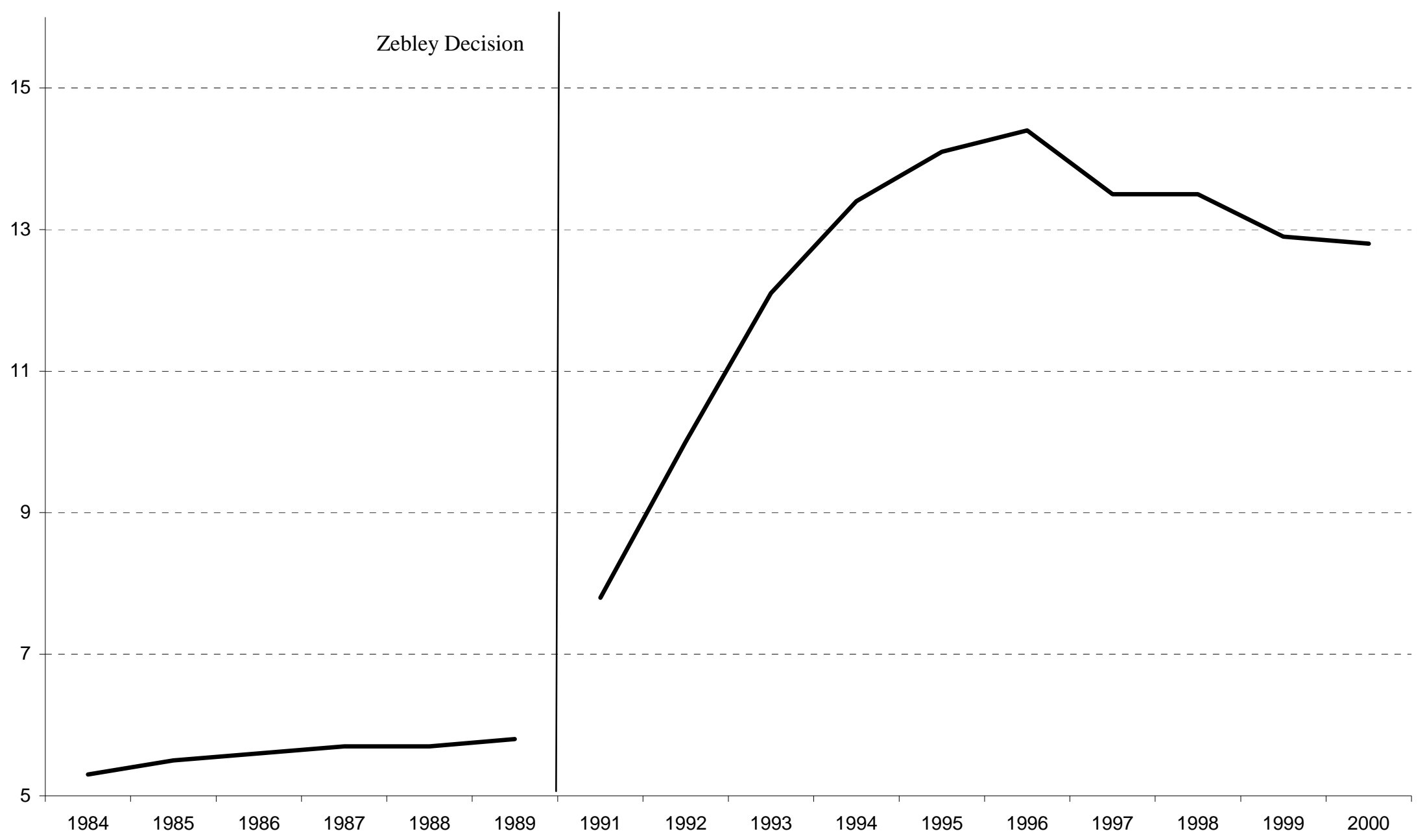

Table shows the percent of SSI recipients under the age of 18. Source: Social Security Administration (2004). 
Figure 4: Growth in Charitable Spending Following the Zebley Decision

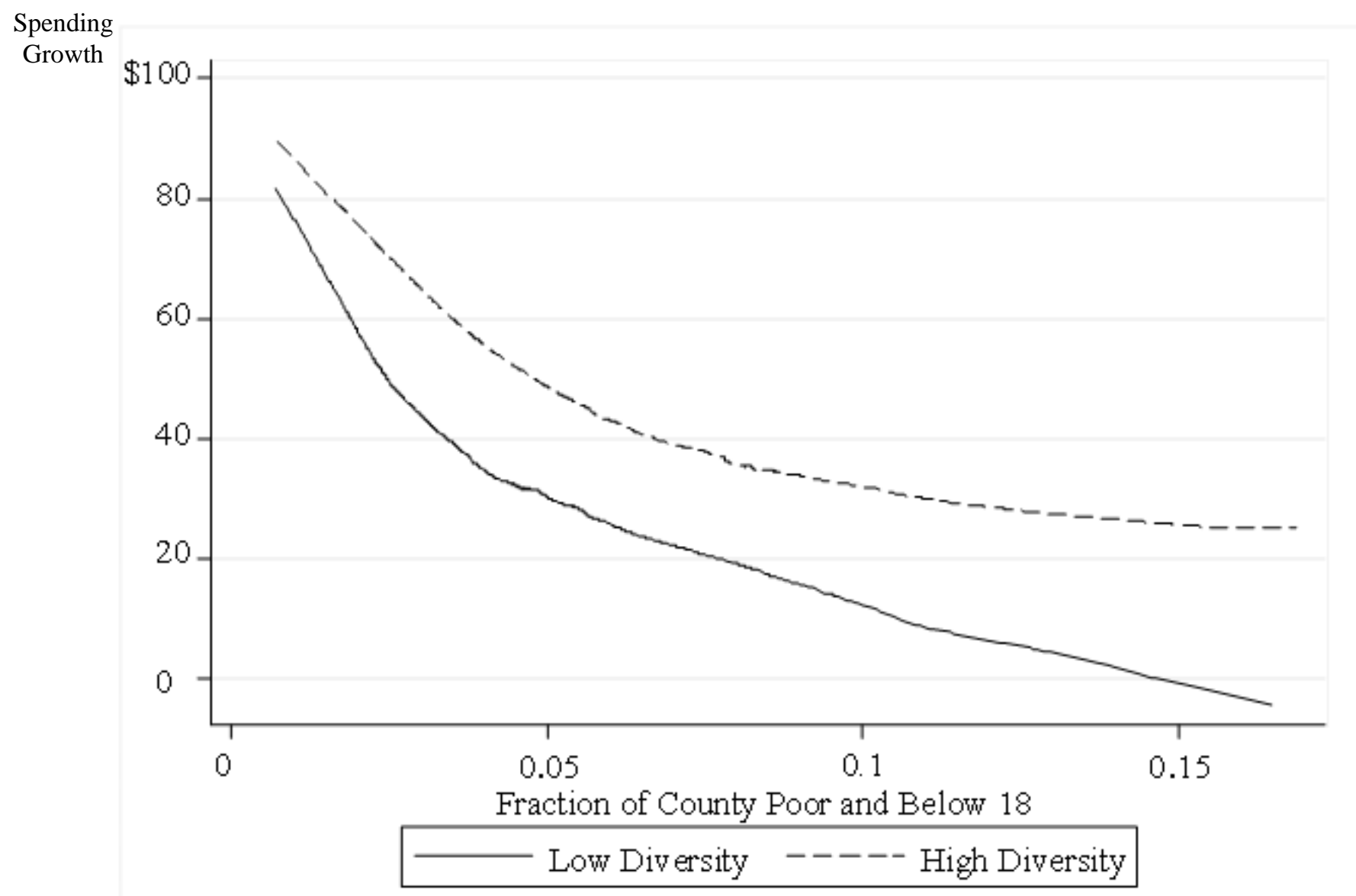

Figure depicts two lowess-curve estimates of the relationship between (a) the fraction of a county's population made up of poor individuals under 18 and (b) the difference in average charitable spending after 1991 relative to before 1991. The "low diversity" curve was calculated for counties having a below-average Herfindahl index score for diversity, the "high diversity" curve uses counties with above average diversity. The lowess curve uses the conventional tricube weighting function to weight observations. 


\section{Figure 5: Distribution of Race Herfindahl Index}

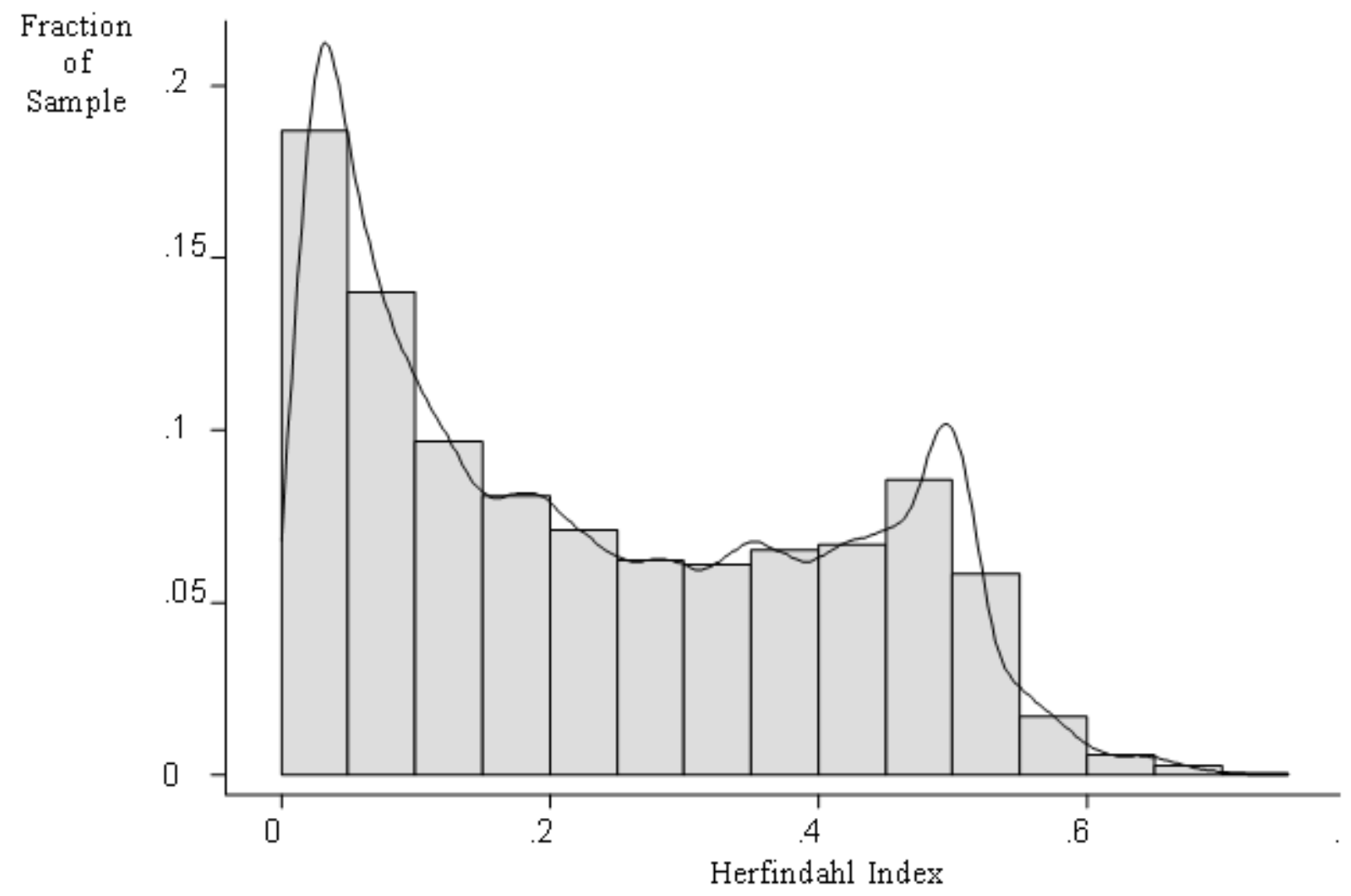

Figure presents a histogram and kernel-density estimate of distribution of Herfindahl index across sample. See text for description of Herfindahl index's construction. 


\section{Table 1: Summary Statistics}

\begin{tabular}{lc}
\hline & Mean \\
\hline Per-member charitable church spending & 192 \\
& {$[128]$} \\
Per-capita SSI Spending & 97.5 \\
& {$[66.4]$} \\
Racial Herfindahl index & 0.228 \\
& {$[0.176]$} \\
Share of population impoverished children & 0.046 \\
& {$[0.025]$} \\
Share of households headed by single female & 0.148 \\
& {$[0.052]$} \\
Unemployment compensation, per capita (1000s) & 0.098 \\
& {$[0.062]$} \\
Share county White & 0.842 \\
& {$[0.156]$} \\
Share county Black & 0.117 \\
Share county American Indian & {$[0.145]$} \\
Share county Asian/Pacific Islander & 0.007 \\
Share county Hispanic & {$[0.025]$} \\
& 0.011 \\
Share county under age 5 & {$[0.027]$} \\
& 0.04 \\
Share county ages 6-18 & {$[0.085]$} \\
& 0.069 \\
Share county ages 65 and over & {$[0.009]$} \\
County population (1000s) & 0.205 \\
& {$[0.02]$} \\
Small church dummy ( $<100$ members) & 0.136 \\
Medium-sized church dummy (100-500 members) & 0.525 \\
& {$[0.499]$} \\
& 5.15 \\
& {$[1.06]$} \\
\hline \hline Log of members & 296 \\
& {$[851]$} \\
& 0.314 \\
& {$[0.464]$} \\
& \\
&
\end{tabular}

Observations: 375,373. Standard deviations in brackets. Each church each year counts as one observation. There are churches in 2,940 counties in the sample. The sample covers UMC churches from 1984 to 2000. Monetary figures in year 2000 dollars. 
Table 2: Diversity and Crowd-out: Selected Coefficients from Basic Regression

\begin{tabular}{|c|c|c|c|}
\hline & IV Regression & $\begin{array}{c}\text { First Stage } \\
\text { Regression (1) }\end{array}$ & $\begin{array}{c}\text { First Stage } \\
\text { Regression (2) }\end{array}$ \\
\hline Per-capita SSI spending & $\begin{array}{c}-0.522 \\
{[0.056]}\end{array}$ & - & - \\
\hline SSI spending*Race Herfindahl & $\begin{array}{c}0.860 \\
{[0.134]}\end{array}$ & - & - \\
\hline Share poor children*Post 1990 & - & $\begin{array}{c}994.5 \\
{[56.97]}\end{array}$ & $\begin{array}{c}34.26 \\
{[12.97]}\end{array}$ \\
\hline Triple Interaction & - & $\begin{array}{l}-814.2 \\
{[96.8]}\end{array}$ & $\begin{array}{c}504.2 \\
{[27.45]}\end{array}$ \\
\hline Race Herfindahl & $\begin{array}{l}-212.9 \\
{[117.2]}\end{array}$ & $\begin{array}{l}-48.8 \\
{[50.6]}\end{array}$ & $\begin{array}{l}-26.64 \\
{[27.67]}\end{array}$ \\
\hline Share poor children & $\begin{array}{c}280.7 \\
{[132.3]}\end{array}$ & $\begin{array}{c}68.48 \\
{[76.68]}\end{array}$ & $\begin{array}{c}-11.22 \\
{[26.41]}\end{array}$ \\
\hline Share single female-headed HHs & $\begin{array}{c}-274.6 \\
{[78.71]}\end{array}$ & $\begin{array}{c}139.2 \\
{[52.41]}\end{array}$ & $\begin{array}{c}60.29 \\
{[20.33]}\end{array}$ \\
\hline Unemployment compensation & $\begin{array}{l}-11.19 \\
{[8.22]}\end{array}$ & $\begin{array}{l}-0.128 \\
{[5.23]}\end{array}$ & $\begin{array}{c}2.44 \\
{[1.91]}\end{array}$ \\
\hline Share population under 5 & $\begin{array}{l}958.3 \\
{[185]}\end{array}$ & $\begin{array}{c}118.5 \\
{[108.3]}\end{array}$ & $\begin{array}{c}113.6 \\
{[34.97]}\end{array}$ \\
\hline Share population 6-18 & $\begin{array}{c}190.3 \\
{[98.84]}\end{array}$ & $\begin{array}{c}-175.4 \\
{[67.62]}\end{array}$ & $\begin{array}{c}37.39 \\
{[21.42]}\end{array}$ \\
\hline Share population over 65 & $\begin{array}{c}506.9 \\
{[87.92]}\end{array}$ & $\begin{array}{c}414.4 \\
{[49.36]}\end{array}$ & $\begin{array}{c}87.54 \\
{[16.98]}\end{array}$ \\
\hline Small church dummy & $\begin{array}{l}-12.87 \\
{[5.75]}\end{array}$ & $\begin{array}{c}1.08 \\
{[0.47]}\end{array}$ & $\begin{array}{c}0.266 \\
{[0.157]}\end{array}$ \\
\hline Medium church dummy & $\begin{array}{c}-6.66 \\
{[3.34]}\end{array}$ & $\begin{array}{c}1.49 \\
{[0.36]}\end{array}$ & $\begin{array}{c}0.351 \\
{[0.140]}\end{array}$ \\
\hline Log members & $\begin{array}{l}-92.23 \\
{[8.88]}\end{array}$ & $\begin{array}{l}-2.47 \\
{[0.51]}\end{array}$ & $\begin{array}{l}-1.10 \\
{[0.20]}\end{array}$ \\
\hline Dependent variable & $\begin{array}{l}\text { Church } \\
\text { Spending }\end{array}$ & SSI Spending & $\begin{array}{c}\text { SSI Spending* } \\
\text { Herfindahl }\end{array}$ \\
\hline Year \& population dummies? & Yes & Yes & Yes \\
\hline Church fixed effects? & Yes & Yes & Yes \\
\hline R-squared & - & 0.96 & 0.98 \\
\hline Observations & 375,373 & 375,373 & 375,373 \\
\hline
\end{tabular}




\section{Table 3: Robustness Tests on Charitable Church Spending}

\begin{tabular}{lcccc}
\hline \hline & $\begin{array}{c}\text { Baseline 2SLS } \\
\text { Regression }\end{array}$ & $\begin{array}{c}\text { OLS Regression on } \\
\text { Church Spending }\end{array}$ & $\begin{array}{c}\text { 2SLS Regression } \\
\text { w/out Church FEs }\end{array}$ & $\begin{array}{c}\text { 2SLS Regression on } \\
\text { Current Expenses }\end{array}$ \\
\hline Per-capita SSI spending & -0.522 & -0.138 & -0.627 & 0.060 \\
& {$[0.056]$} & {$[0.031]$} & {$[0.081]$} & {$[0.037]$} \\
SSI spending*Race Herfindahl & 0.860 & 0.589 & 0.575 & 0.047 \\
& {$[0.134]$} & {$[0.116]$} & {$[0.145]$} & {$[0.095]$} \\
Year \& population dummies? & Yes & Yes & Yes & Yes \\
Church fixed effects? & Yes & Yes & No & Yes \\
Include regressors from Table 2? & Yes & Yes & Yes & Yes \\
Observations & 375,373 & 375,373 & 375,373 & 375,373 \\
\hline \hline
\end{tabular}

All regressions except column 2 are 2SLS regressions. Robust standard errors, clustered by county, in brackets. The First three columns show regressions of per-member church spending on SSI. The third column does not include church (or county) fixed effects. The last column uses per-member current operating expenses as the dependent variable; current expenses include for example spending on upkeep, insurance, supplies and utilities. 
Table 4: Additional 2SLS Regressions on Charitable Church Spending

\begin{tabular}{|c|c|c|c|c|c|c|}
\hline & \multicolumn{3}{|c|}{ "Continuous Interaction } & \multicolumn{3}{|c|}{ "Non-Continuous Interactions } \\
\hline & $\begin{array}{l}\text { Extra Spending } \\
\text { Controls on RHS }\end{array}$ & $\begin{array}{l}\text { Use All Means- } \\
\text { Tested Spending }\end{array}$ & $\begin{array}{c}\text { Use All Means- } \\
\text { Tested Spending } \\
\text { but Medicaid }\end{array}$ & SSI Spending & $\begin{array}{c}\text { All Means-Tested } \\
\text { Spending }\end{array}$ & $\begin{array}{c}\text { All Means-Tested } \\
\text { Spending But } \\
\text { Medicaid } \\
\end{array}$ \\
\hline Per-capita government spending & $\begin{array}{c}-0.505 \\
{[0.057]}\end{array}$ & $\begin{array}{l}-0.084 \\
{[0.009]}\end{array}$ & \begin{tabular}{c|}
-0.506 \\
{$[0.059]$}
\end{tabular} & $\begin{array}{l}-0.422 \\
{[0.051]}\end{array}$ & $\begin{array}{l}-0.069 \\
{[0.009]}\end{array}$ & $\begin{array}{c}-0.394 \\
{[0.05]}\end{array}$ \\
\hline Gov’t spending*Race Herfindahl & $\begin{array}{c}0.877 \\
{[0.136]}\end{array}$ & $\begin{array}{c}0.11 \\
{[0.014]}\end{array}$ & $\begin{array}{c}0.839 \\
{[0.104]}\end{array}$ & - & - & - \\
\hline Gov’t spending*In-between dummy & - & - & - & $\begin{array}{c}0.192 \\
{[0.062]}\end{array}$ & $\begin{array}{c}0.024 \\
{[0.006]}\end{array}$ & $\begin{array}{c}0.218 \\
{[0.046]}\end{array}$ \\
\hline Gov’t spending*Heterogeneous dummy & - & - & - & $\begin{array}{c}0.314 \\
{[0.059]}\end{array}$ & $\begin{array}{c}0.039 \\
{[0.006]}\end{array}$ & $\begin{array}{c}0.309 \\
{[0.044]}\end{array}$ \\
\hline Government Spending Includes & SSI & $\begin{array}{l}\text { SSI, Medicaid, } \\
\text { Food Stamps, } \\
\text { AFDC/TANF }\end{array}$ & $\begin{array}{c}\text { SSI, Food Stamps, } \\
\text { AFDC/TANF }\end{array}$ & SSI & $\begin{array}{l}\text { SSI, Medicaid, } \\
\text { Food Stamps, } \\
\text { AFDC/TANF }\end{array}$ & $\begin{array}{l}\text { SSI, Food Stamps, } \\
\text { AFDC/TANF }\end{array}$ \\
\hline Year \& population dummies? & Yes & Yes & Yes & Yes & Yes & Yes \\
\hline Church fixed effects? & Yes & Yes & Yes & Yes & Yes & Yes \\
\hline Include regressors from Table 2 ? & Yes & Yes & Yes & Yes & Yes & Yes \\
\hline Include middle \& heterogeneous dums? & No & No & No & Yes & Yes & Yes \\
\hline Observations & 375,373 & 375,373 & 375,373 & 375,373 & 375,373 & 375,373 \\
\hline
\end{tabular}

All regressions are 2SLS regressions on charitable church spending, per member. Robust standard errors, clustered by county, in brackets. The "in-between" dummy equals unity if a county has a Herfindahl index value between 0.2 and 0.4 , the heterogeneous dummy equals unity if the Herfindahl index is above 0.4 . The in-between dummy equals unity for 94,906 observations and the heterogeneous dummy is unity for 85,690 observations. A Wald test that the spending*in-between dummy equals the spending*heterogeneous dummy in column 4 yields a test statistic of $\chi^{2}[1]=3.61, p=0.057$. For column 5 , a Wald test that the spending*inbetween dummy equals the spending*heterogeneous dummy yields $\chi^{2}[1]=7.00, p=0.008$. For column 6 , a Wald test that the spending*in-between dummy equals the spending*heterogeneous dummy yields $\chi^{2}[1]=4.13, p=0.042$. A Wald test that all three listed coefficients are equal is rejected at the one percent level for each regression in columns 4,5 , and 6 . The last three columns use three instruments: The first instrument is the standard one, share of poor children in a county times a post 1990 dummy. The second instrument is an interaction of the standard instrument and a dummy for whether a county is an "in-between" community. The final instrument is an interaction of the standard instrument and a dummy for whether a county is a diverse community. 
Table 5: Diversity and Crowd-out: Separate Samples

\begin{tabular}{|c|c|c|c|}
\hline & $\begin{array}{c}\text { Homogeneous } \\
\text { Counties }\end{array}$ & $\begin{array}{c}\text { In-Between } \\
\text { Counties }\end{array}$ & $\begin{array}{c}\text { Heterogeneous } \\
\text { Counties }\end{array}$ \\
\hline $\begin{array}{l}\text { IV Regression of Church Spending on SSI } \\
\text { Per-capita SSI spending }\end{array}$ & $\begin{array}{c}-0.412 \\
{[0.051]}\end{array}$ & $\begin{array}{c}-0.366 \\
{[0.124]}\end{array}$ & $\begin{array}{c}-0.073 \\
{[0.107]}\end{array}$ \\
\hline $\begin{array}{l}\text { First Stage Regression of SSI Spending on Instrument } \\
\text { Share impoverished children*Post } 1990 \text { dummy }\end{array}$ & $\begin{array}{c}1,095 \\
{[55.05]}\end{array}$ & $\begin{array}{c}422.1 \\
{[67.42]}\end{array}$ & $\begin{array}{c}581 \\
{[52.1]}\end{array}$ \\
\hline $\begin{array}{l}\text { Reduced Form Regression of Church Spending on Instrument } \\
\text { Share impoverished children*Post } 1990 \text { dummy }\end{array}$ & $\begin{array}{l}-450.8 \\
{[47.11]}\end{array}$ & $\begin{array}{l}-154.6 \\
{[52.98]}\end{array}$ & $\begin{array}{l}-42.30 \\
{[60.94]}\end{array}$ \\
\hline $\begin{array}{l}\text { IV: Church Spending on SSI w/other spending on RHS } \\
\quad \text { Per-capita SSI spending }\end{array}$ & $\begin{array}{l}-0.39 \\
{[0.05]}\end{array}$ & $\begin{array}{l}-0.308 \\
{[0.134]}\end{array}$ & $\begin{array}{l}-0.118 \\
{[0.119]}\end{array}$ \\
\hline $\begin{array}{l}\text { IV: Church Spending on all Means-Tested Spending } \\
\text { Per-capita government spending }\end{array}$ & $\begin{array}{l}-0.074 \\
{[0.009]}\end{array}$ & $\begin{array}{l}-0.049 \\
{[0.017]}\end{array}$ & $\begin{array}{l}-0.018 \\
{[0.026]}\end{array}$ \\
\hline $\begin{array}{l}\text { IV: Church Spending on all Means-Tested Spending but Medicaid } \\
\quad \text { Per-capita government spending } \\
\text { Year \& population dummies? } \\
\text { Church fixed effects? } \\
\text { Include regressors from Table 2? } \\
\text { Observations }\end{array}$ & $\begin{array}{l}-0.353 \\
{[0.044]} \\
\text { Yes } \\
\text { Yes } \\
\text { Yes } \\
194,777\end{array}$ & $\begin{array}{l}-0.228 \\
{[0.080]} \\
\text { Yes } \\
\text { Yes } \\
\text { Yes } \\
94,906\end{array}$ & $\begin{array}{l}-0.101 \\
{[0.150]} \\
\text { Yes } \\
\text { Yes } \\
\text { Yes } \\
85,690\end{array}$ \\
\hline
\end{tabular}

Each coefficient is from a separate regression. Per-capita SSI spending is the dependent variable for regressions in the second row; for all other regressions the dependent variable is per-member charitable church spending. Robust standard errors, clustered by county, in brackets. The sample of homogeneous counties includes counties with Herfindahl index values below 0.2; the "in-between" sample includes counties with Herfindahl index values between 0.2 and 0.4 , and the heterogeneous sample includes counties with Herfindahl index values above 0.4. Per-capita government spending in the bottom row equals spending on SSI, Food Stamps, and AFDC/TANF. Per-capita government spending on the nextto-bottom row includes SSI, Food Stamps, AFDC/TANF, and Medicaid. 
From Tables 2 and 3

Table A1: Results Using Alternate Index Construction

\begin{tabular}{|c|c|c|c|c|c|c|}
\hline & $\begin{array}{c}\text { 2SLS } \\
\text { Regression } \\
\end{array}$ & $\begin{array}{c}\text { First Stage } \\
\text { Regression (1) } \\
\end{array}$ & $\begin{array}{c}\text { First Stage } \\
\text { Regression (2) } \\
\end{array}$ & $\begin{array}{l}\text { OLS Reg. on } \\
\text { Church } \\
\text { Spending } \\
\end{array}$ & $\begin{array}{c}\text { 2SLS Reg. } \\
\text { w/out Church } \\
\text { FEs } \\
\end{array}$ & $\begin{array}{c}\text { 2SLS Reg. on } \\
\text { Current } \\
\text { Expenses } \\
\end{array}$ \\
\hline Per-capita SSI spending & $\begin{array}{c}-0.561 \\
{[0.058]}\end{array}$ & - & - & $\begin{array}{c}-0.122 \\
{[0.032]}\end{array}$ & $\begin{array}{c}-0.629 \\
{[0.082]}\end{array}$ & $\begin{array}{c}0.085 \\
{[0.040]}\end{array}$ \\
\hline SSI spending*Race Herfindahl & $\begin{array}{c}0.777 \\
{[0.132]}\end{array}$ & - & - & $\begin{array}{c}0.526 \\
{[0.121]}\end{array}$ & $\begin{array}{c}0.642 \\
{[0.198]}\end{array}$ & $\begin{array}{c}0.031 \\
{[0.102]}\end{array}$ \\
\hline Share poor children*Post 1990 & - & $\begin{array}{c}950.65 \\
{[63.971]}\end{array}$ & $\begin{array}{c}28.22 \\
{[14.83]}\end{array}$ & - & - & - \\
\hline Triple Interaction & - & $\begin{array}{c}-739.84 \\
{[100.07]} \\
\end{array}$ & $\begin{array}{l}510.44 \\
{[29.61]}\end{array}$ & - & - & - \\
\hline
\end{tabular}

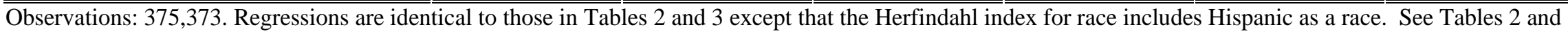

3 and the bottom of this table for more details.

From Table 4

\begin{tabular}{|c|c|c|c|c|c|c|}
\hline & $\begin{array}{l}\text { Extra Spending } \\
\text { Controls on RHS } \\
\end{array}$ & $\begin{array}{l}\text { Use All Means- } \\
\text { Tested Spending }\end{array}$ & $\begin{array}{c}\text { Use All Means- } \\
\text { Tested Spending } \\
\text { but Medicaid }\end{array}$ & SSI Spending & $\begin{array}{c}\text { All Means-Tested } \\
\text { Spending } \\
\end{array}$ & $\begin{array}{c}\text { All Means-Tested } \\
\text { Spending But } \\
\text { Medicaid } \\
\end{array}$ \\
\hline Per-capita government spending & $\begin{array}{c}-0.556 \\
{[0.060]}\end{array}$ & $\begin{array}{c}-0.093 \\
{[0.010]}\end{array}$ & $\begin{array}{c}-0.524 \\
{[0.059]}\end{array}$ & $\begin{array}{c}-0.416 \\
{[0.049]}\end{array}$ & $\begin{array}{c}-0.069 \\
{[0.008]}\end{array}$ & $\begin{array}{c}-0.386 \\
{[0.048]}\end{array}$ \\
\hline Gov’t spending*Race Herfindahl & $\begin{array}{c}0.782 \\
{[0.135]}\end{array}$ & $\begin{array}{c}0.105 \\
{[0.013]}\end{array}$ & $\begin{array}{c}0.769 \\
{[0.096]}\end{array}$ & - & - & - \\
\hline Gov’t spending*In-between dummy & - & - & - & $\begin{array}{c}0.164 \\
{[0.059]}\end{array}$ & $\begin{array}{c}0.020 \\
{[0.006]}\end{array}$ & $\begin{array}{c}0.192 \\
{[0.047]}\end{array}$ \\
\hline Gov’t spending*Heterogeneous dummy & - & - & - & $\begin{array}{c}0.307 \\
{[0.057]}\end{array}$ & $\begin{array}{c}0.039 \\
{[0.006]}\end{array}$ & $\begin{array}{c}0.304 \\
{[0.042]}\end{array}$ \\
\hline
\end{tabular}

Observations: 375,373. Regressions are identical to those in Table 4 except that the Herfindahl index for race includes Hispanic as a race. See Table 4 and the bottom of this table for more details. The Wald tests described under Table 4 were conducted for these regressions and the resulting test statistics were very similar to those described under Table 4. 
Table A1: Results Using Alternate Index Construction, continued

From Table 5

\begin{tabular}{|c|c|c|c|}
\hline & $\begin{array}{l}\text { Homogeneous } \\
\text { Counties }\end{array}$ & $\begin{array}{c}\text { In-Between } \\
\text { Counties }\end{array}$ & $\begin{array}{l}\text { Heterogeneous } \\
\text { Counties }\end{array}$ \\
\hline $\begin{array}{l}\text { IV Regression of Church Spending on SSI } \\
\text { Per-capita SSI spending }\end{array}$ & $\begin{array}{l}-0.436 \\
{[0.054]}\end{array}$ & $\begin{array}{l}-0.564 \\
{[0.135]}\end{array}$ & $\begin{array}{l}-0.116 \\
{[0.108]}\end{array}$ \\
\hline $\begin{array}{l}\text { First Stage Regression of SSI Spending on Instrument } \\
\text { Share impoverished children*Post } 1990 \text { dummy }\end{array}$ & $\begin{array}{l}1,055.71 \\
{[57.31]}\end{array}$ & $\begin{array}{l}500.71 \\
{[75.10]}\end{array}$ & $\begin{array}{l}557.54 \\
{[46.50]}\end{array}$ \\
\hline $\begin{array}{l}\text { Reduced Form Regression of Church Spending on Instrument } \\
\text { Share impoverished children*Post } 1990 \text { dummy }\end{array}$ & $\begin{array}{l}-460.39 \\
{[47.57]}\end{array}$ & $\begin{array}{l}-282.45 \\
{[56.47]}\end{array}$ & $\begin{array}{l}-64.82 \\
{[59.27]}\end{array}$ \\
\hline $\begin{array}{l}\text { IV: Church Spending on SSI w/other spending on RHS } \\
\text { Per-capita SSI spending }\end{array}$ & $\begin{array}{l}-0.424 \\
{[0.055]}\end{array}$ & $\begin{array}{l}-0.527 \\
{[0.146]}\end{array}$ & $\begin{array}{l}-0.154 \\
{[0.123]}\end{array}$ \\
\hline $\begin{array}{l}\text { IV: Church Spending on all Means-Tested Spending } \\
\text { Per-capita government spending }\end{array}$ & $\begin{array}{l}-0.077 \\
{[0.009]}\end{array}$ & $\begin{array}{l}-0.081 \\
{[0.016]}\end{array}$ & $\begin{array}{l}-0.027 \\
{[0.026]}\end{array}$ \\
\hline $\begin{array}{l}\text { IV: Church Spending on all Means-Tested Spending but Medicaid } \\
\quad \text { Per-capita government spending } \\
\text { Observations }\end{array}$ & $\begin{array}{l}-0.371 \\
{[0.047]} \\
181,589\end{array}$ & $\begin{array}{l}-0.380 \\
{[0.091]} \\
91,571\end{array}$ & $\begin{array}{l}-0.156 \\
{[0.148]} \\
102,213\end{array}$ \\
\hline
\end{tabular}

Regressions are identical to those in Table 5 except that the Herfindahl index for race includes Hispanic as a race. See Table 5 and the bottom of this table for more details.

The index is constructed as before except that individuals identifying themselves as Hispanic are classified in a new Hispanic category, and the proportion Hispanic is subsequently included in the index's construction. The mean of the index in the sample is 0.25 , with a maximum value of 0.76 . As before, the "in-between" dummy equals unity if a county has a Herfindahl index value between 0.2 and 0.4 , and the heterogeneous dummy equals unity if the Herfindahl index is above 0.4 . 